\title{
PATOLOGÍAS DE LA LIBERTAD (V). DEPRESIÓN Y SUICIDIO: LA CONSTRICCIÓN DEL SER
}

\section{PATHOLOGIES OFFREEDOM(V).DEPRESSIONAND SUICIDE: THE CONSTRICTION OF THE BEING}

\author{
Manuel Villegas Besora \\ ORCID: https://orcid.org/0000-0002-5584-8469 \\ Doctor en Psicología, Universidad de Barcelona
}

Cómo referenciar este artículo/How to reference this article:

Villegas, M. (2021). Patologías de la libertad (v). Depresión y suicidio: La constricción del ser. Revista de Psicoterapia, 32(119), 211-269. https://doi.org/10.33898/rdp.v32i119.861

\section{Resumen}

Este artículo se inscribe en la serie "patologías de la libertad" dedicada a la comprensión de los "trastornos neuróticos” más frecuentes, desde la perspectiva del análisis existencial. Versa sobre depresión y suicidio, dado que la depresión es uno de los desencadenantes más habituales del suicidio, en su triple vertiente ideacional, tentativa o ejecutiva. Desde el punto de vista existencial la depresión significa el hundimiento del núcleo central de la existencia. Esta deja de tener sentidoy proyección en el mundo sea natural (Umwelt), social (Mitwelt) o personal (Eigenwelt). Se analiza esta relación a través de tres casos, especificos para cada uno de estos tres mundos.

Palabras clave: depresión, existencia, suicidio, Umwelt, Mitwel, Eigenwelt.

\begin{abstract}
This article is part of the series "pathologies of freedom" dedicated to the understanding of the most frequent "neurotic disorders", from the perspective of existential analysis. It treats on depression and suicide, since depression is one of the most common triggers of suicide, in its threefold ideation, attempt or execution. From an existential point of view, depression means the sinking of the central nucleus of existence. It ceases to make sense and projection in the world whether natural (Umwelt), social(Mitwelt) or personal(Eigenwelt). This relationship is analyzed through three cases, specific to each of these three worlds.

Keywords: depression, existence, suicide, Umwelt, Mitwel, Eigenwelt.
\end{abstract}


Solo hay un problema filosófico verdaderamente serio, el suicidio. Juzgar si la vida vale la pena de ser vivida es responder a la cuestión fundamental de la filosofía.

--Albert Camus. El mite de Sísif

En trabajos anteriores hemos analizado algunas de las patologías neuróticas mayores, si se nos permite hablar en estos términos, desde la perspectiva de los conflictos de la libertad. Así la agorafobia, como restricción del espacio (Villegas, 1995), la obsesión, como constricción de la espontaneidad (Villegas, 2000) y la anorexia, como restricción de la corporalidad (Villegas, 1997), contrapuesta a la bulimia, como su descontrol (Villegas, 2004). Sin embargo, a pesar de habernos referido a ella en diferentes escritos (Villegas, 2011), no hemos dedicado todavía un monográfico específico al estudio de la depresión como tal.

Al intentar integrar el presente estudio sobre la depresión en la serie de patologías de la libertad, la primera cuestión que se plantea es la de encontrar su encaje en la lógica discursiva que la estructura. ¿De qué manera la depresión se puede considerar un conflicto de la libertad? La respuesta se presenta de forma casi automática: la depresión afecta, ya desde su fundamento ontológico, a la libertad de ser o para ser.

En términos existenciales se puede considerar la depresión como la "constricción del ser" o, en términos filosóficos, del "Dasein". Como quiera que esta expresión puede resultar de difícil comprensión fuera del ámbito de la filosofía, podemos traducirla como la constricción o limitación del mundo, entendido como espacio simbólico de proyección de la existencia. La palabra ex-sistencia significa literalmente estar (sistere) fuera (ex), de donde el concepto heideggeriano de " $D a$ Sein”: “el ser ahí”, que está fuera. ¿Fuera, dónde?: en el mundo.

En el contexto de la filosofía existencial, el mundo se entiende como espacio simbólico de proyección propia y relación con los demás. El ser humano se halla situado en relación al mundo natural, el Umwelt, o mundo de la naturaleza, de la ecología, el mundo de la corporalidad, de la sexualidad, de la salud y de la enfermedad, de la vida y de la muerte; al Mitwelt o mundo de la presencia social y de las relaciones interpersonales: el mundo de la familia, de la pareja, de las amistades, de la profesión o del trabajo, de la fama y de la imagen; y el Eigenwelt o mundo propio: el mundo de la intimidad, la autoconciencia, la identidad personal, la percepción de sí mismo, de la autonomía y la responsabilidad. El fallo, fracaso, ausencia, pérdida, constricción, negación, exclusión o limitación en cualquiera de estos mundos puede ser motivo de depresión, es decir de impotencia o falta de poder ser.

\section{Fallo Ontológico}

El primero de los fallos afecta a la vida misma, lo podemos considerar un fallo ontológico, supone la negación del ser natural (Umwelt), su existencia se considera ilegítima. El ser es directamente eliminado (muerte o suicidio). Una gran parte de 
los suicidios responden a sentimientos de fracaso o invalidación ontológica. “Al mirarme, mi madre veía a otra persona. Yo sentía que no existía, que es lo mismo que sentirse insustancial... o que era un ser equivocado, debería haber sido una niña, en sustitución de mi hermana muerta", escribe Paul Williams (2014) en El Quinto Principio en relación al descuido y abandono del que fueron víctimas tanto él como su hermana Patricia. Una experiencia de invalidación ontológica que no tiene que terminar necesariamente en suicidio, sino que, inversamente, con frecuencia, como en el caso de Paul, puede dar lugar a una vida resiliente y satisfactoria.

La persona que siente rabia o desprecio contra sí misma y desea morir, lo expresa en ocasiones a través de afirmaciones categóricas del tipo: "No tendría que haber nacido" o con ensoñaciones de muerte, como liberación:

Algunos luchan por vivir; se aferran a la vida, lo darían todo, mientras que otros, al menos yo, deseo en secreto una muerte plácida, que se acabe esta tortura... Diría que soy horrible por decir todo esto, al menos lo sentiría de alguien como yo, pero la primera que paga las consecuencias soy yo, así que tampoco voy a reprochármelo, que ya tengo suficiente tormento con lo que tengo...

\section{Exclusión Social}

Otra fuente de invalidación existencial es la exclusión social (Mitwelt), por la que alguien es perseguido, excluido, discriminado, humillado o deshonrado en el ámbito de las relaciones interpersonales, sean éstas públicas o privadas. Valeria Ugazio (2018) la coloca en la base de la depresión desde su perspectiva social, sistémica o relacional:

Las personas con organización depresiva, provienen de familias en las que predomina la semántica de la pertenencia, centrada en dos polaridades semánticas nucleares: inclusión/exclusión, honra/deshonra. Estar incluido en la familia, en la parentela, en la propia estirpe, en la comunidad es lo más importante precisamente porque en el mismo núcleo familiar hay quien está excluido, marginado, rechazado. La expulsión del grupo, la falta de una pertenencia familiar son vividas como una deshonra irreparable, mientras el bien más grande es estar enraizados y ser honrados o reconocidos dentro de los propios grupos de pertenencia, de la familia a la comunidad, o incluso en el trabajo.

\section{Fracaso Existencial}

La reacción depresiva responde muchas veces al fracaso existencial, como consecuencia de un itinerario vital equivocado, que podríamos calificar de "proyecto existencial frustrado", como percepción de pérdida de sentido o como ausencia de proyección en el futuro. En el momento en que, por la causa que sea, tenemos la sensación de no encontrarle sentido a nuestro existir eso lleva como consecuencia la reacción depresiva acompañada muchas veces de ideas de muerte o suicidio, 
puesto que lo que está en juego es la continuidad del propio mundo (Eigenwelt).

La sensación de vacío existencial adquiere distintos matices según el momento vital de la persona. Desde la perspectiva de la edad puede vivirse como nostalgia, desengaño o depresión frente a la percepción de inutilidad de cualquier esfuerzo por alcanzar la felicidad, como un fracaso ante una vida perdida o como una falta de proyecto que desarrollar en este mundo. Esta sensación de vacío, o falta de sentido de la vida, es típica de las crisis del ciclo vital. El texto que transcribimos a continuación pertenece a una joven que no vislumbraba un horizonte para su vida donde proyectarse:

La vida ya no tiene sentido para mí, ya no tengo ilusiones, ya no puedo luchar más, ya estoy cansada de llorar y de engañarme, pensando que el día siguiente será distinto. Ya no puedo más. Estoy desesperada porque sé que nunca me curaré, porque ya lo he probado todo y nada funciona... La única solución es desaparecer, pero hay algo que me lo impide; y no quiero impedimentos, no quiero conformidad. La única solución es desaparecer, pero no sé cómo hacerlo sin que nadie sufra por mí. Por eso, si no hubiera nacido, todo sería mejor, tanto para mí como para la gente que sufre por mí.

Laura, en cambio (Balcells, 2017), de 52 años, desde una perspectiva del ciclo medio de la vida, no solamente carece de perspectiva de futuro, sino que considera un fracaso todo su pasado y un incordio para los demás, su presente:

Terapeuta (T).: ¿Sabrías identificar los pensamientos que te llevan a fantasear con el suicidio?

Laura (L).: Sí, son cosas que me hago o pienso yo: como que no les importo a mis padres, que sin mi estarían todos más tranquilos, no sufrirían pensando "a ver qué nos depara ahora ésta." Estoy cansada de tantas cosas que no puedo solucionar... como mi malestar... No hago nada bien, cada vez que abro la boca, si digo lo que pienso, si hago lo que quiero hacer. No he sido una madre que se haya hecho respetar, he dado, poco afecto a mi marido... Solo pienso en mí, soy egoísta... he dicho cosas que han herido a los demás o les han hecho daño, soy un desastre; no sirvo para nada... No me gusta cuando miro atrás en mi vida y menos cuando miro hacia delante. Soy una preocupación constante para los míos, suegra y amigas incluidas. Si yo no estuviera, lo pasarían mal unos días, pero luego estarían mejor. Estarían en paz.

T.: Dices que has pensado muchas veces en las maneras de morir.

L.: Sí... cuando estoy en casa: tirarme por el balcón, como si fuese un accidente. Lo haría de noche, cuando todos duermen, porque siempre me salva mi marido, asi lo conseguiría de una vez. También lo pienso en la calle: que me atropelle un coche, o mejor un camión. No miro al cruzar la carretera, pero paran y me pitan. Así, también parecería un accidente. 
En las páginas siguientes vamos a considerar en detalle a través del estudio de tres casos reales, pero con nombres ficticios, la relación entre depresión y (intentos de) suicidio con el colapso existencial en cualquiera de estos tres mundos: Umwelt, Mitwelt y Eigenwelt.

\section{Umwelt}

\section{Ellen West: Antes Muerta que Vieja, Gorda y Fea}

"Me encantan los dulces / El cielo sería morirse en una cama de helado de vainilla...” (Birdart, 1990). Estos son los primeros versos con que inicia el poema de Fank Bidart (1990), escrito a mediados de los años setenta, dedicado a Ellen West, convertido recientemente en el libreto de la ópera de cámara del mismo nombre, musicada por Ricky Ian Gordon y estrenada en Julio de 2019 en la Ópera de Saratoga (EE.UU). Y continúa:

Pero mi verdadero yo/ es delgado/ solo silueta/ de gestos delicados/ el tipo de chica rubia y elegante/ cuyo cuerpo es la imagen de su alma. / Mis médicos me dicen / que debo abandonar este ideal; / pero no..., no puedo. Solo para mi esposo / no soy simplemente un caso. /Pero es tonto. / Se casó con un pedazo de carne / y pensaba que era una esposa. (Birdar, 1990)

El caso de Ellen West muestra a la perfección el conflicto existencial de una persona que se debate inútilmente entre su ser natural (Umwelt) y su ser ideal (Eigenwelt). Hasta el punto de haber dejado escrito en su diario "Créame Dios mío otra vez, pero créame mejorada”. Esta lucha imposible le lleva finalmente al suicidio a los 33 años de edad.

\section{Genograma}

¿Pero quién era Ellen West? Ellen West es el seudónimo de una paciente que fue admitida el 14 de enero de 1921 en la clínica Bellevue de Kreuzlingen, de la que Binswanger era superintendente, y que murió después de tomar una dosis letal de veneno en la noche del 2 al 3 de abril del mismo año, a la edad de 33 años.

A través de los textos de Binswanger (1945) es posible extraer algunos datos relativos a su historia y a su familia, que permiten obtener el siguiente Genograma (figura 1): 
Figura 1

Genograma de Ellen West

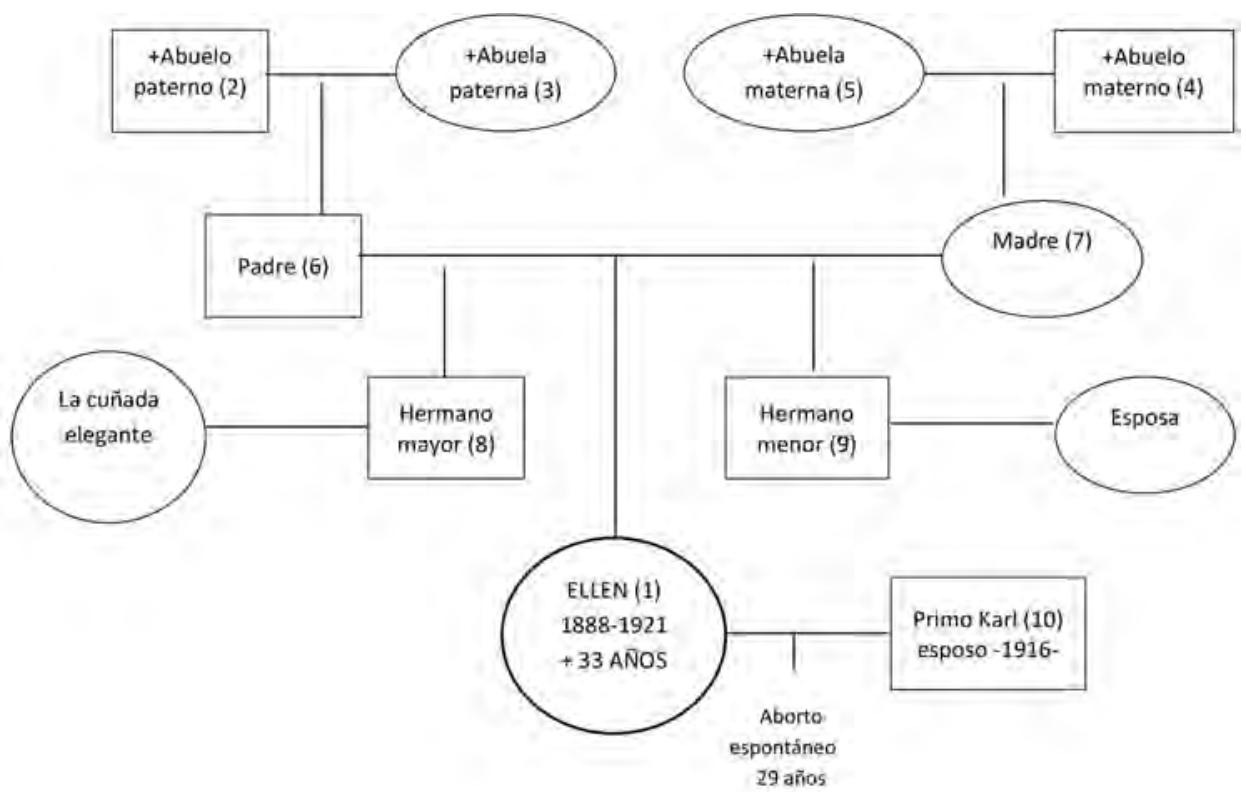

1) Ellen West. De familia judía tanto por línea paterna, como materna. 18881921.

2) Abuelo paterno: autócrata, severo.

3) Abuela paterna: amable, conciliadora, semanas calladas.

4) Abuelo materno: muerto joven.

5) Abuela materna: aspecto saludable. Segundas nupcias. Longeva. Demencia senil

6) El padre: se le describe autocontrolado, reservado, constante y activo, delicado y sensible; nervioso, padece insomnio. Tuvo seis hermanos. El primero, una chica que enloqueció el día de la boda. El segundo, asceta riguroso. El tercero se suicidó a los 25 años. El cuarto también se suicidó en un ataque de melancolía. El quinto y el sexto padecieron esclerosis mental.

7) La madre, hija única por parte de padre. Tuvo cinco hermanos por parte de madre (de las segundas nupcias), nerviosos, enclenques, pero longevos.

8) Hermano mayor (cuatro años más). Cabello negro, equilibrado y alegre.

9) Hermano menor. Rubio. Episodios psiquiátricos. Artista delicado.

10) Karl, marido y primo hermano de Ellen, se casan en 1928. 


\section{Cronograma}

Ellen West nació a finales de julio de 1888, de familia judía, burguesa bienestante, probablemente en Norteamérica, aunque la mayor parte de su vida se desarrolló en Suiza. Era la segunda de tres hermanos. Una mirada global sobre su historia nos permite descubrir puntos de inflexión en esta existencia que marcan el paso hacia un punto sin retorno. La representación sintética de la vida de Ellen West describe una línea de proyección que apunta fuerte en la adolescencia y juventud, pero que con el tiempo, va replegándose estérilmente sobre sí misma hasta su autodestrucción. En síntesis puede representarse a través del siguiente cronograma:

- 1888 - 1904. (De 0 a 16 años) Nace en el continente americano, probablemente (EE.UU). De familia judía, que posteriormente se traslada a Suiza. Del periodo de la infancia no hay documentación. Le gusta aprender e ir a la escuela. Sus juegos son más bien infantiles hasta los 16 años, donde empieza a mostrar intereses sociales.

- 1904 - 1910. (Entre 16 y 22 años) En este periodo sus intereses sociales se manifiestan en estudios y lecturas de filosofía y literatura. Se hace referencia de varios viajes a Paris, Sicilia y más en concreto dos viajes trasatlánticos. Trabaja en una sala de lectura infantil y obtiene la "Matura" en economía. Practica equitación. Aparecen algunos flirteos amorosos y algunos escarceos con la comida y el ayuno.

- 1911 - 1913 (Entre 23 y 25 años) Con 23 años obtiene el magisterio. Conoce un estudiante de pensamiento revolucionario, por quien se siente atraída. Llegan a un compromiso que posteriormente se rompe por exigencia paterna. Entremedio una aventura desagradable con el profesor de equitación. Continúan los balanceos entre comer y ayunar.

- 1914 - 1916. (Entre 26 y 28 años) Tercer viaje transatlántico. Su vida sentimental da bandazos. Ahora aparece Karl, el primo, que la pretende, pero a la vez se producen reencuentros con el estudiante, replanteando la ruptura. La sintomatología alimentaria continúa por un igual. Sus actividades físicas incluyen gimnasia, excursiones. Sigue cursos de música y trabaja en una guardería infantil.

- 1916 - 1918. (Entre 28 y 30 años) Se produce la ruptura definitiva con el estudiante y contrae matrimonio con su primo Karl. Habiendo quedado embarazada, sufre un aborto, tal vez debido a su estado físico, debilitado por las fuertes dietas.

- 1918 - 1920. (Entre 30 y 32 años) Aumenta su dedicación a obras sociales. Trabaja en una agencia de bienestar social. Conferencias, teatro, excursiones. Su conducta alimentaria presenta mayores desequilibrios: atracones, laxantes, dietas de frutas, largas caminatas. La curva ponderal que podemos trazar a partir de los documentos es la siguiente: 72kgs. (28 años), 47 (31 años), 42 (32 años), 46/47 (33 años). Su estado de salud general empeora (aparece la amenorrea, cesan las relaciones sexuales, etc.) lo que la lleva 
a visitar muchos médicos, ginecólogos y finalmente también neurólogos. Inicia también psicoanálisis.

- 1920 - 1921. (33 años) Deja el trabajo. Sus actividades se centran en lecturas, asistir a clases en la universidad, teatro y paseos. Los desórdenes alimentarios son cada vez más graves. Se suceden las visitas a internistas, neurólogos. Un segundo psicoanálisis, también interrumpido. Cuatro intentos de suicidio. Fracasado un primer internamiento en clínica psiquiátrica, es admitida en el sanatorio de Kreuzlingen en enero de 1921, dirigido por Ludvig Binswanger. Se da de alta voluntariamente en abril del mismo año y se suicida a la vuelta a casa con una dosis letal de veneno, a los 33 años de edad.

\section{La Mirada Diagnóstica}

En escritos anteriores (Villegas, 1981, 1989) nos hemos ocupado ampliamente de este caso que, sin embargo, nos parece tan relevante para el tema que estamos tratando que no podemos evitar volver a traerlo aquí de nuevo, desde la perspectiva de la relación entre depresión y suicidio, dentro del marco de comprensión existencial con que hemos planteado este estudio.

Sin embargo, para no repetirnos en la exposición del caso nos hemos tomado la libertad de contarlo de manera diferente, enfocándolo no como una historia clínica, debidamente comentada, que es lo que hace Binswanger (1945); ni como un monólogo poético, que es lo que hace el poema de Bidart (1990), sino como un diálogo imaginario, producido en la actualidad entre Ellen West y un terapeuta, que la entrevista a través de una plataforma virtual desde el más allá.

\section{Entrevista con Ellen West}

Ellen West (E).: Hola, buenos dias.

Terapeuta (T):: Buenos días.

E.: Veo que no me reconoces.

T.: No, la verdad. ¿Quién eres, cómo te llamas?

E.: Soy Ellen West, aunque no me llamo así.

T.: ;Ah! claro. Este es el nombre ficticio que te puso Binswanger, cuando en 1945 publicó tu caso. Pero los psicólogos no hemos llegado a saber nunca cómo te llamabas de verdad.

E.: Ni te lo diré ahora.

T.: De acuerdo, pues, te llamaremos Ellen.

E.: Asi me gusta... Este es el nombre con el que se me conoce en la historia de la psiquiatría... Me he conectado por Skype, porque me gustaría poder aclararme sobre una cuestión de diagnóstico en mi caso.

T.: Tu caso... Tienes razón, fue muy discutido. Te llegaron a ver muchos psiquiatras y cada uno dio su opinión, sin llegar a ponerse nunca de acuerdo. Según Ludwig Binswanger, un primer psicoanalista te diagnosticó histeria. 
El segundo, neurosis obsesiva grave con oscilaciones maníaco-depresivas. El médico de cabecera, psicastenia. El propio Kraepelin dictaminó una simple melancolía. Finalmente tanto Binswanger como Bleuler lo vieron como un caso de esquizofrenia progresiva (schizophrenia simplex). Todos convinieron "que no se trataba de un caso de neurosis obsesiva ni de psicosis maníaco-depresiva y que no era posible ningún tratamiento de eficacia segura".

E.: Oh, y es más; aun después de muerta, se ha continuado discutiendo mi diagnóstico. Carl Rogers (1961), desde una perspectiva humanista; Ronald Laing (1982) con un enfoque existencial, o sistémico por parte de Salvador Minuchin (1984), también se refirieron a mí en sus escritos, con la intención de liberarme de la mirada diagnóstica.

T.: Pero, ¿no decías que querías aclarar tu diagnóstico?

E.: Si; y en la actualidad, después de investigar por Internet he llegado a la conclusión de que el diagnóstico que psiquiatras y psicólogos escribirían hoy por hoy en sus informes psicológicos sería el de Trastorno de la Conducta Alimentaria (TCA).

T.: Y, ¿cómo has llegado a esta conclusión?

E.: En base a que mi conducta cuadra con los sintomas que caracterizan el TCA: miedo intenso a la obesidad, rechazo a mantener el peso corporal dentro de los límites de la normalidad y amenorrea en las mujeres.

T.: ¿Y todo eso se cumplía en tu caso?

E.: Efectivamente, entre los veintiocho, en que empecé a desarrollar el TCA, y los treinta y tres años, en que morí, mi peso descendió de los 72 a los 42 quilos. En cuatro años llegué a perder 30 quilos. Al año, también se me retiró la regla.

T.: Y respecto al otro criterio del que hablabas, ¿el miedo a la obesidad? E.: Tal como dejé escrito en mi diario "Algo en mí se rebela contra la idea de ponerme gorda, de ponerme sana, de desarrollar unos mofletes rojos, de convertirme en mujer sencilla y robusta, como corresponde a mi verdadera naturaleza".

T.: Veo que te has estudiado muy bien los fundamentos de tu autodiagnóstico. En aquella época ni siquiera existía la categoría psiquiátrica del TCA. ¿Habría cambiado algo, si los manuales de psiquiatría de aquel entonces lo hubiesen contemplado?

E.: Ahora me doy cuenta de que no. Total no deja de ser una etiqueta descriptiva "Trastorno de Conducta Alimentaria", porque la persona no come bastante, hace conductas restrictivas o purgativas, o porque come compulsivamente y vomita a continuación. Pienso que lo importante es comprender qué es lo que motiva esta conducta. Comprender para cambiar. T.: Totalmente de acuerdo. Entonces, imagino que, igual que te has informado sobre los criterios de tu diagnóstico, habrás reflexionado sobre el 
sentido de lo que te sucedía.

E.: Creo que hay muchos elementos en juego. Entre los años de psicoanálisis que hice en vida y las lecturas que he podido hacer después aquí en este estado atemporal, he ido atando algunos cabos.

T.: Como ¿cuáles?

E.: Para empezar, he repasado mi vida. Me he dado cuenta que de mi infancia recuerdo muy poco. Sé que naci a finales del siglo XIX, en una familia judía, en América. Era la segunda de tres hermanos. Mis recuerdos empiezan a tomar forma desde que nos trasladamos a vivir a Suiza. Aquí continué mis estudios en un colegio femenino. De mí decían en casa que "era buena estudiante, que me gustaba ir al colegio y era muy ambiciosa, lloraba si no conseguía el primer puesto en la clase y no dejaba de asistir a la escuela, ni que estuviera enferma".

T.: Vaya, una buena estudiante.

E.: Sí, pero por lo que cuentan muy infantil. Hasta los 16 años todavía me chupaba el pulgar. No estaba por tonterías de "novietes", ni cosas así. Más bien mis juegos eran de muchacho; prefería llevar pantalones.

T.: O sea, que en aquella época no te preocupabas por estar más gorda o más flaca.

E.: No. Más bien quería sentirme fuerte. En un poema escrito a los diecisiete años expresaba mi ardiente deseo de ser chico "porque asi podría ser soldado, no temer ningún enemigo y morir gozosamente blandiendo la espada". T.: Una visión más bien épica...

E.: Heroica y romántica. En aquel tiempo me consideraba una especie de Jeanne de Arc, llamada a realizar alguna misión especial; leía mucho, me ocupaba intensamente de problemas sociales, sentía profundamente el contraste entre mi propia situación social burguesa y la miserable de las "masas" y soñaba con mejorar la condición de los pobres.

T.: Y, ¿cuáles eran tus lecturas escogidas?

E.: Entre mis autores preferidos figuraban Bakunin, Pisarev y J. P. Jacobsen, de quien a los 17 años lei la obra Niels Lyhne, que me condujo al ateísmo. T.: Te inspirabas en el nihilismo ruso que exige el desprendimiento de las riquezas y compartir la vida con los más pobres.

E.: En escritos de aquella época hago proclamas encendidas como esta: "Quisiera abandonar mi casa y mis padres como un nihilista ruso, para ir a vivir entre los más pobres de los pobres y hacer propaganda en favor de la gran causa”.

T.: Osea, que te estabas convirtiendo en una revolucionaria familiary social. E.: Sentía una tensión entre mis ideales y mi condición social contra la que me rebelaba. Tenía 21 años y se esperaba de mí que me condujese como una muñeca muda y estúpida, que ha aprendido a sonreír. "No soy una muñeca -protestaba- soy un ser humano con sangre roja y una mujer con corazón 
trepidante. No puedo respirar en esta atmósfera de cobardía e hipocresía; quiero hacer algo más y acercarme más a mi ideal, a mi magnifico ideal... ¡Libertad! ¡Revolución!'”... "No hablo de la liberación del alma, hablo de la liberación real, tangible del pueblo de las cadenas de sus opresores. ¿Tendré que decirlo todavía más claro? Quiero un gran revolución, un alzamiento en masa que se extienda por todo el mundo y derribe todo el orden social". T.: No te andabas con chiquitas... y ¿qué se hizo de tus anhelos revolucionarios?

E.: Se fueron deshinchando como un globo. Lo máximo que llegué a conseguir fue montar una biblioteca infantil y trabajar en alguna guardería o agencia social. Nada que pudiera compararse a la Revolución de Octubre. El trabajo ocupaba no un lugar de transformación de la realidad, sino de adormidera de mis inquietudes.

T.: Y ¿cómo te explicas este bajón en tu proyección existencial?

E.: Cuestión de amores. A parte de algunos flirteos y una aventura desagradable con mi profesor de equitación, tuve otros dos amores, antes de casarme. Un primer amor romántico a los 20 años, con un extranjero que conocí en un viaje transatlántico. A los 23 inicié una relación con un estudiante universitario que correspondía mucho más a mi fantasía de poder vivir una vida diferente, alternativa a la hipocresía de la vida burguesa. Esta relación sufrió muchas vicisitudes, debido a la interferencia de mi familia. Pasamos del compromiso a la ruptura en más de una ocasión, entre los 24 y los 28 años. Finalmente tuve que romper con él para casarme con mi primo hermano, Karl.

T.: Y ¿cómo se llegó a este punto?

E.: A mi padre no le gustaba este estudiante. Decía que no correspondia a mi clase social. Y no cejó hasta que acepté casarme con mi primo. Fue un matrimonio forzado y esto era lo que me impedia quererle. Poco antes de morir le escribí a Karl: "En aquel tiempo tú eras la vida que yo estaba dispuesta a aceptar a cambio de mi ideal (representado por el estudiante universitario). Pero era una resolución forzada, tomada artificialmente, sin haber madurado por dentro. Por eso no resultó y empecé a mostrarme en oposición a ti”.

T.: Parece que estabas atrapada entre un conflicto de fidelidades, por un lado, a ti misma, a tus sentimientos y a tus ideales y, por otra, a tu familia, a tu estirpe, a tu clase social.

E.: En efecto; y aqui, quien tuvo que pagar los platos rotos fue mi marido. "Únicamente me convertiré en tu mujer -le decía en la carta-cuando renuncie finalmente al ideal de mi vida. iPobre..., tener que estar decepcionándote continuamente!”.

T.: Y tú, tras este ideal, te debatías entre una imagen de revolucionaria y otra de pertinencia a una clase social burguesa, que reforzaba la de una 
mujer elegante y frágil, como tu cuñada, interesada únicamente por los asuntos familiares y mundanos, ajena a cualquier preocupación social. Este conflicto entre estas dos imágenes contradictorias adquirió una dimensión transcendental, que se puede entender como una lucha entre el destino y la libertad. Pero por lo que explicas en esta lucha terminaste por ceder a las presiones externas, renunciando a tu libertad.

E.: Ya me quejaba yo, entonces. Día tras día me daba cuenta que estaba malgastando mi juventud y mi salud mental. Ni que fuera de manera retórica me preguntaba: ¿Para qué me dio la naturaleza salud y ambición? Seguramente no para ahogarla y encadenarla, ni dejarla languidecer entre las cadenas de la vida rutinaria, sino para servir a la miserable humanidad. Las cadenas de hierro de la vida vulgar: las cadenas del convencionalismo, de la propiedad y del confort, de la gratitud y la consideración, y las cadenas del amor, las más fuertes de todas. Sí, estas son las que me tienen presa, las que me impiden mi vuelo caudal, mi completa entrega al mundo del sacrificio y la lucha por la que suspira toda el alma”.

T.: Entonces, si entiendo bien, fue en este contexto donde se gestó tu TCA. E.: Exactamente.: Un trastorno alimentario complejo que siguió un recorrido variado. Empezó a los 20 años con el primer amor romántico con comer, ayunos y caminatas. Y continuó en los años siguientes, desde los 23, oscilando entre anorexia y bulimia, en paralelo a las vicisitudes de la relación con el estudiante: A los 25 se produjo una primera ruptura con el estudiante y empecé el noviazgo con mi primo, Karl, con quien me casé a los 28.

T.: ¿Y aqui termina tu historia amorosa con los hombres?

E.: No. Mientras tanto volvió a aparecer el estudiante al que yo había estado añorando todo este tiempo, hasta que rompi con él definitivamente bajo la presión de mis padres, que me obligaron a escoger entre él o mi primo Karl. Pronto me quedé embarazada, pero perdí la criatura en un aborto espontáneo.

T.: ¿Y qué pasó con tu sintomatología durante este periodo?

E.: Continuaba con altos y bajos, dietas y largas caminatas. Se fue complicando a más con problemas endocrinos, amenorrea, etc. me visitaron neurólogos y ginecólogos, que me recetaron de todo. A partir de los 30 empecé a trabajar en una agencia de bienestar social; pero esto no cambió nada.

T.: ¿Afectó todo esto tu relación marital?

E.: Después del aborto corté las relaciones sexuales con él. Estaba desconcertado. Mi sintomatología empeoraba más y más. Aumenté las dietas, añadiendo laxantes, jugos de naranja descomunales... mi peso estaba bajando en picado. Todo el mundo estaba preocupado por mí. Y entonces inicié un largo recorrido por una serie de psicoanalistas. Internamientos 
en sanatorios. Me visitaron cuatro psiquiatras, uno tras otro. Nadie sabía qué hacer conmigo.

T.: En todo este trajín, ¿te sentiste apoyada, acompañada o comprendida por alguien durante este periodo?

E.: Sí, por mi marido, pobre. Encima, por indicación del analista, nos tuvimos que separar un tiempo. Sin embargo, a raíz de mis primeros intentos de suicidio, volvió a mi lado, llegando a internarse conmigo en el sanatorio. T.: Pareceque te quería... Primeros intentos de suicidio, ¿es que hubo otros? E.: Sí, cuatro como mínimo y de las formas más variadas: llegué a ofrecerle dinero a un cazador, que me encontré por el bosque, para que me matase de un tiro. Consideraba la muerte como la mayor felicidad de la vida, sino la única. Pensaba que sin la esperanza del final, la vida sería intolerable. Lo único que me consolaba un poco era la certeza que, tardara más o menos, llegaría la muerte. A veces desafiaba a mi marido, retándole: "Karl, si de verdad me quieres, mátame!".

T.: ¿Qué consideras que te condujo a estos extremos?

E.: Sentía que todo mi desarrollo interior se paraba, que se cegaba totalmente el manantial de vida y expansión, porque se había apoderado de mi alma una sola idea, algo indeciblemente ridículo. Como mi único criterio de acción era averiguar si una cosa me engordaba o adelgazaba, pronto perdieron las cosas su significado intrínseco. Ya nada me interesaba. Mis pensamientos estaban fijados únicamente en mi cuerpo, en mi comida, en mis laxantes. Mi interior estaba tan intimamente fusionado con mi cuerpo, que ambos formaban una sola unidad, constituyendo juntos mi yo individual, nervioso e ilógico.

T.: ¿Fue esta sensación la que te llevó a probar el psicoanálisis?

E.: Sí. Yo quería desmenuzar los impulsos desconocidos que eran más fuertes que mi razón y me forzaban a organizar mi vida de acuerdo con una pauta orientada a adelgazar, cada vez más. Sin embargo, cuanto más intentaba analizarme, menos me aclaraba... Pero, ¿dónde estaba realmente el error? T.: Tal vez se trataba de un conflicto que se expresaba a través del cuerpo. Antes has dicho; "Mi interior estaba tan intimamente fusionado con mi cuerpo, que ambos formaban una sola unidad”. En él tomaban cuerpo, valga la redundancia, las contradicciones entre el ideal y la realidad, representada también por tus dos amantes, el estudiante y el marido. El cuerpo por su dimensión pública y observable se convierte en elemento de controversia entre el mundo propio y el ajeno, en su símbolo o encarnación. Por esto es tan importante su imagen.

E.: Una intuición parecida la tuve yo cuando escribi en mi diario: "En todos los puntos soy sensata y tengo claridad de ideas; solo en éste estoy loca; estoy arruinándome en mi lucha contra mi naturaleza. La fatalidad me quiso obesa y fuerte, pero yo quiero ser estilizada y delicada" 
T.: Estas dos visiones contrapuestas, la imagen y la contra-imagen, se corresponden con la oposición entre el ideal revolucionario (el tuyo y el del estudiante) y el burgués (el de la tu familia y tu marido). Ambos convergían en tu cuerpo: si querías ser revolucionaria tenías que estar fuerte para luchar, pero a la vez estar delgada como los pobres a quienes querías redimir. Si escogías ser burguesa tenías que comer hasta el hartazgo, pero, a la vez, si querías convertirte en la mujer elegante de un burgués, tenías que ser delicada y delgada, pero, al mismo tiempo, lo bastante fuerte para poder darle un hijo. Realmente, tu cuerpo no podía resolver el dilema y entró en la contradicción de comer y vomitar, de tener hambre y hacer dieta, se perdió en la aporía de la anorexia purgativa.

E.: Esta contradicción fue tan fuerte, que al final opté por el suicidio. Matando el cuerpo me libraba de la tortura obsesiva del comer. Mis últimos sueños iban todos en la misma dirección. En uno de ellos, premonitorio de mi suicidio, soñé que en un viaje por mar me tiraba per el tragaluz del camarote. El estudiante y mi marido se lanzaban al agua para salvarme y me hacían la respiración artificial.

T.: Los hombres a los que habias cedido tu existencia... y, ¿cómo terminaba el sueño?

E.: De nuevo, ya en tierra, me harté de bombones e hice las maletas.

T.: Necesitabas comer como mujer de carne y hueso que eras, pero no podias continuar haciéndolo indefinidamente, porque esto te llevaba a aumentar cada vez más tus contradicciones.

E.: Lo que me habría llevado inevitablemente, con el paso del tiempo, a convertirme en una mujer "vieja, gorda y fea", imagen que no podía soportar de mí misma.

T.: Decidiste irte. Hiciste las maletas... Era la manera de "retomar las riendas de tu vida".

E.: Sí, yo siempre lo había sostenido: "los escogidos de los dioses mueren jóvenes". Yo no quería morir vieja y frustrada, porque me consideraba llamada a una gran misión. Mi lema era "Aut Caesar, aut nihil" (O César o nada). Y fue: nada; porque mi gran sueño de juventud, no se cumplió en la edad madura. Mis ansias de libertad derivaron en dependencia de los otros y de mi imagen.

T.: La tuya fue una existencia frustrada. Te quedaste en promesa. Atrapada en el ideal de estar delgada y carecer de cuerpo. Con un yo dividido entre tu fantasía revolucionaria y tu realidad burguesa. Luchaste con nobleza de espíritu hasta que la facticidad física y social te superó y preferiste una muerte digna, a una vida incoherente contigo misma. 


\section{Por una Hermenéutica Existencial del Caso de Ellen West}

Hasta aquí el diálogo imaginario con Ellen West que nos ha permitido recomponer su historia personal y penetrar en su mundo vivencial a través de sus propias palabras, tomadas de sus diarios, cartas y anotaciones. Está claro, a través de él, el diagnóstico que recibiría su caso en nuestros días, a través de los criterios de clasificación del Manual Diagnóstico y Estadístico de los Trastornos Mentales ( $5^{\mathrm{a}}$ ed.; DSM-5; American Psychiatric Association, 2014): Trastorno de la Conducta Alimentaria: anorexia purgativa (TCA).

Algunos han querido ver, además, un problema de identidad de género en referencia a que, de niña y adolescente, hasta los dieciséis años, prefería los juegos de niño y llevar pantalones. El mismo poema de Bidart lo insinúa cuando pone en su boca la cuestión:

¿Por qué soy una chica? / Les pregunto a mis médicos / y me dicen que no saben, / que es "un hecho". / Pero esto tiene todas estas consecuencias; / y a veces, incluso me siento como una chica.

Pero estos autores obvian que a partir de los 17 empezó a mostrarse muy femenina y con ello a preocuparse por su imagen corporal. El poema de Bidart lo plantea así en la escena del restaurante que sigue a continuación en que ella se identifica, como amante, con la mujer de la pareja que se sienta en la mesa de al lado:

Ella era hermosa / con rasgos afilados y claros... Y él, no podía recordar

/ cuándo había visto a un hombre tan atractivo.../ Era casi una versión masculina de ella./

Tuve la repentina y loca idea de querer ser su amante...

Luego se regodea en describir cómo se intercambian la comida en sus bocas: "Su comportamiento de alguna manera me enfermó.../ Me invadió una inmensa depresión... / Sabía que para convertirme en esposa / tendría que renunciar a mi ideal".

Todas estas categorías clasificatorias pertenecen a lo que Laing (1982) llamó "la mirada diagnóstica”, que con toda probabilidad no hizo más que reforzar la sintomatología de Ellen West, depauperando hasta tal punto su existencia que al final ya solo vivía para sus síntomas. Esta obsesión, causa de frecuentes inculpaciones y autorrecriminaciones, la llevó finalmente al suicidio, después de cuatro intentos fallidos y provocaciones directas al homicidio, a un cazador y a su esposo.

Este final de la historia (el suicidio) y el evidente fracaso de su recorrido vital, más allá de la clara sintomatología anoréxica purgativa, o las cuestiones relativas a la identidad de género, nos llevan a rastrear en sus orígenes la formación de un proyecto existencial fracasado.

\section{Por una Hermenéutica Existencial del Caso de Ellen West}

El proyecto existencial deEllen West se puede analizar detalladamente siguiendo la evolución de su ideal: un ideal que pronto experimentará la escisión entre dos mundos, el propio (Eigenwelt) y el ajeno o social (Mitwelt), por incompatibilidades mutuas. 
Esta lucha entre los dos mundos ideales enfrentados y su propia realidad la llevarán a la autodestrucción final, a través de la eliminación del cuerpo natural (Umwelt), punto de encuentro de todos los conflictos y contradicciones entre ambos mundos.

Empecemos primero por describir la representación que Ellen West hace idealmente de sí misma (Eidos). Ella es, ante todo una mujer revolucionaria: sus amores auténticos tienen que ver con esa imagen revolucionaria. El primer amor romántico y el de un estudiante universitario responden a una fantasía (tal vez posibilidad) de vivir una vida distinta, alternativa a la hipocresía de la vida burguesa. Este ideal era el que le impedía convertirse en la mujer de su primo Karl con el que finalmente se desposó y a quien escribía en una carta poco antes del desenlace final: "Únicamente me convertiré en tu verdadera mujer cuando renuncie finalmente al ideal de mi vida. Y esto se me hace tan difícil que hoy día estoy desesperada como hace unas semanas. ¡Pobre..., tenerte que estar decepcionando continuamente! ”.

La visión que tiene ella del mundo circundante (Mitwelt) configura, sin embargo, su Antieidos. Ellen West pertenece a una clase social burguesa en la que se refuerza una imagen de mujer elegante y frágil, como su cuñada, interesada únicamente por los asuntos familiares y mundanos, ajena a cualquier preocupación social: "Tengo 21 años y se supone que debo callar o sonreír estólidamente como una muñeca”.

El padre le impone un marido de acuerdo con su clase social, exigiéndole una separación temporal del estudiante universitario y se espera de ella que sea una esposa y madre de pies a cabeza. Del conflicto entre estas dos imágenes contradictorias y su facticidad corporal (Umwelt) y social (Mitwelt) surge una lucha entre el destino y la libertad que adquiere tintes de tragedia. En esta lucha Ellen West cede a las presiones del medio, renunciando a su libertad: “ $i Q u e ́$ lástima ésta mi joven vida, y qué pecado desperdiciar mi salud mental!

Así continúa en su diario, escribe Binswanger (1945), aireando el odio que siente contra el lujo y la buena vida que le rodea y lamentando su cobardía y su debilidad, al no ser capaz de superar los obstáculos y sobreponerse a las circunstancias, y al dejarse ablandar, tan joven "por la fealdad y el aire viciado de la rutina diaria". Hay en este abandono progresivo de sus ideales auténticos un fracaso en la realización histórica de sus proyectos y una renuncia a asumir su propia responsabilidad.

Deja sus decisiones más importantes en manos de los demás, sin atreverse a asumir las riendas de su propia existencia. En realidad, tiene miedo de estar sola, no se aleja ni un momento de sus padres, le acompaña su nodriza a todas partes e incluso su marido se interna con ella en el sanatorio. Se fía más del criterio ajeno que del suyo. Su dependencia del mundo circundante es cada día mayor: "Aunque de pequeña prescindía en absoluto de la opinión de los demás, ahora está totalmente pendiente de lo que piensan los otros sobre su aspecto y su obesidad” observa Binswanger (1945) el 22 de enero del último año de su vida. Ellen West transforma su ideal de cambiar el mundo por el de cambiar su propia naturaleza, sacrificando su cuerpo en honor de aquél.

Su existencia ideal solo era posible idealmente y no encontraba puntos de anclaje 
en la realidad. Desde su enrocamiento narcisista, Ellen West no acepta la facticidad y por eso quiere huir de este mundo. La muerte no es para ella el límite de la vida que posibilita el despliegue de la existencia, sino el fin que la niega. Ellen West pasa del deseo romántico de morir joven por alguna causa digna y gloriosa a considerar indecorosa su vida e indigna de ser vivida:

La vida se ha convertido para mí en un campo de concentración, y yo ansio la muerte con el mismo ardor con que el pobre soldado cautivo en Siberia ansia regresar a su patria... ;Karl (dirigiéndose al marido), si me quieres, dame muerte!

Esta negación de la propia existencia se polariza en el cuerpo con el que se halla fundida y se transforma en una lucha absurda por comer y des-comer: " $\mathrm{Mi}$ yo interior está tan íntimamente fusionado con mi cuerpo, que ambos forman una unidad, constituyendojuntos mi “yo individual”, nervioso ilógico. Mis pensamientos están fijos exclusivamente en mi cuerpo, mi comida, mis laxantes". Lo que hace que se detenga "todo desarrollo interior y toda vida real". Su ideal revolucionario -"antiguos planes e ilusiones que nunca llegaron a realizarse"- se han transformado en una "idea fija", primero, la de no engordar, para ser substituida después por "el ideal de ser delgada, de carecer de cuerpo". Esta idea se va a convertir en el tema dominante de su existencia. Así se lo hace saber a su marido durante una de las largas caminatas que emprenden juntos. Este tema ya no le abandonará y, a partir de los 32 años, ocupará prácticamente todo el espacio existencial:

Yo quería averiguar los impulsos desconocidos que eran más fuertes que mi razón y me forzaban a organizar toda mi vida de acuerdo con una pauta que me daban hecha. El objetivo de esta pauta era adelgazar. Cuando intento analizar todo eso no saco nada en limpio, sino cualquier teorización, cualquier elucubración... Pero ¿dónde, dónde está realmente la equivocación?

Intentando dar respuesta a esta pregunta, Binswanger (1945) sitúa el error de Ellen West en su rebelión contra el propio destino, contra la forma en que la persona ha sido "lanzada a la existencia". En estos casos la existencia pretende ser distinta de lo que es y puede ser, con lo que va contra su estructura, intentando romper sus moldes, a la vez que se aferra desesperadamente a su propio ser. Pero esta estructura no puede romperse y menos destruirse sin reafirmarla una y mil veces, aunque de una forma anormal.

Si la persona queda fijada a esta forma inauténtica de existencia, a esta afirmación negativa de sí misma, pierde la elasticidad necesaria para acomodarse a la situación interna y externa. Ello sucede porque el vacío existencial que se produce es ocupado inexorablemente por el Mitwelt, la regulación heteronómica o socionómica. El Mitwelt no responde a la idiosincrasia de una persona, sino al estándar común a las otras personas extrañas y, como tal, le es ajeno, pero termina por poseerla.

Con ello, el sujeto se ve sometido a la apreciación de los demás, supeditado a la valoración del mercado, en otras palabras, queda objetivado o alienado. Como 
resultado pasa a ocupar el primer plano el elemento que más se presta a la objetivación, el cuerpo. El cuerpo por su dimensión pública y observable se convierte, de este modo, en el elemento de controversia entre el mundo propio y el ajeno, en el síntoma de su fracaso existencial. Ambos mundos tienen un enemigo común, el cuerpo (Umwelt) que para el primero es antitético a la espiritualidad, mientras que para el segundo es antitético a la elegancia y a su vez el primero y el segundo luchan entre sí a causa de la clase social (revolucionaria -burguesa) y esta lucha se encarna o expresa a través del cuerpo.

Eso es así, efectivamente, en el caso de Ellen West, la cual en su intento desesperado por ser distinta de lo que es, llega a pedir al Creador "que la cree por segunda vez, pero un poco mejorada", y como ello no sucede, termina por eliminar "la manzana de la discordia", su propio cuerpo, dándose muerte de forma calculada y fría, después de haberse puesto en paz consigo misma y su apetito.

Adestacar, como anécdota significativa, que la tarde anterior a su muerte "toma crema de chocolate y huevos de Pascua; da un paseo con su marido...; se encuentra de un humor positivamente jovial; parece haberse disipado hasta el último vestigio de tormenta" (Binswanger, 1945). Uno de los últimos sueños, recogidos en sus notas, constituía el testimonio de una muerte anunciada, hasta el último detalle:

Soñé algo maravilloso: había estallado la guerra. Yo tenía que ir al frente. Me despido de todo el mundo con la gozosa esperanza de MORIR pronto. Me alegro de poder COMER de todo antes del fin; me comí un gran pastel de moca.

Ellen West tenía clara conciencia de haber cometido un error, el de haber confundido su "ideal con una ficción". Esta ficción era la delgadez. La delgadez era el punto de encuentro que le permitía ser idealmente espiritual (revolucionaria) y ser aceptada socialmente (burguesa); no podía verse a sí misma en ninguno de los mundos, si no era bajo el prisma de la delgadez. Pero ese ideal le imposibilitaba ser realmente ella misma: una mujer de carne y hueso, revolucionaria, activa, esposa y madre.

Ella había temido que al engordar disgustaría a su novio anterior (el estudiante) $\mathrm{y}$, en todo caso, identificaba la delgadez con un tipo más distinguido e intelectual y la gordura con un tipo de judío burgués. A su vez gordura (grossese -embarazo, en francés-) estaba relacionada con maternidad. Cuando se enteró por el dictamen del ginecólogo que no lograría sus aspiraciones, como madre, de llegar a tener hijos, a pesar de renunciar al más alto tipo de intelectualidad "entonces decidió vivir para su idea sin inhibiciones y empezó a comer y a tomar grandes dosis diarias de laxantes".

Lo que rechaza Ellen West no es el alimento, sino la materialidad, aunque no tiene otro campo de batalla que una corporalidad escindida entre las dimensiones gordura/delgadez.

Como no puede ser en realidad inmaterial intenta al menos ser máximamente delgada. Su obsesión es ponerse “cada vez más delgada”, hasta carecer de cuerpo. Ellen West, quiere ser delgada porque le repugna la materia. En realidad, desearía 
“carecer de cuerpo”. De modo que rechazando la corporalidad (atributos corporales, sexo, gordura, etc.) rechaza propiamente la corporeidad (ser cuerpo). ¿Qué conseguiría si imaginariamente pudiera llegar a existir careciendo de cuerpo?: la superación de los límites e, incluso, de las necesidades y a la vez la posibilidad de derribar el mundo burgués que odia. La realización perfecta del nihilismo. Podría reconciliar de este modo el mundo propio (Eigenwelt) y el mundo social (Mitwelt), a costa de su naturaleza (Umwelt) corporal (anorexia/suicidio).

\section{El Conflicto Existencial de Ellen West}

La naturaleza del conflicto existencial de Ellen West se puede exponer gráficamente a través de la macroestructura de su discurso, extraíble de la consideración de sus escritos como un texto global, tal como se presenta en la siguiente gráfica (figura 2).

Partiendo de la relación conflictiva existente entre los mundos personal (Eigenwelt) y social (Mitwelt) donde se proyecta su existencia es fácil organizar las relaciones estructurales que se establecen entre ellos. Éstas son de oposición irreconciliable entre sí y confluyen en el núcleo central, ocupado por el Umwelt, sometiéndolo a una tensión insoportable, atravesado por todas las contradicciones del sistema discursivo que dan origen al TCA: delgadez/espiritualidad vs. gordura/ corporalidad.

El mundo propio (Eigenwelt) está constituido por un discurso ideológico que busca el cambio social a través de la revolución. El mundo social (Mitwelt) está formado por un contexto familiar y económico burgués, cargado de expectativas relativas a su condición femenina y de clase. Ambos mundos están saturados de implicaciones contradictorias entre sí. El mundo propio (Eigenwelt) exige sacrificio, pobreza, lucha interna y externa, y en última instancia ascetismo que, llevado a su extremo, implica carecer de cuerpo: inmaterialidad o espiritualidad. El mundo social conlleva comodidad, riqueza, improductividad económica, "muñeca improductiva" para dedicarse en cuerpo y alma a ser esposa de un marido burgués y madre de unos hijos que aseguren la descendencia familiar.

Pero, ¿cómo se puede ser burguesa y revolucionaria, a la vez? Sólo de una manera, desplazando el conflicto hacia el cuerpo en lugar de la acción, siguiendo una estrategia parecida a la somatización en las enfermedades psicosomáticas donde, en vez de expresar o solucionar los conflictos o las contradicciones internas o externas, éstas se mantienen irresolubles, mientras el organismo enferma.

De este modo el cuerpo se convierte en el lugar de expresión de todas las contradicciones (Bordo, 1993). Eliminándolo, mediante el suicidio, se acabarán para siempre. El yo natural o corporal queda escindido entre el mundo ideal y el social. Pero, ¿por qué el cuerpo? Porque a través de su imagen se expresa su pertenencia social. Un cuerpo demacrado nos remite a una condición social de pobreza. También la obesidad mórbida, lo hace. Pero a su vez, un cuerpo delgado, nos remite a una elegancia de clase social bien alimentada. 
Ellen West no puede estar ni gorda ni flaca. Si gorda, no puede ser revolucionaria, pero si flaca no puede luchar por llevar a término la revolución. Pero tampoco podrá ser madre si no engorda (grossesse = embarazo en francés), pero si engorda dejará de ser la muñeca, esposa del marido burgués. Estas tensiones dividen su yo natural (Umwelt) haciéndola oscilar entre el atracón y los laxantes.

Su conflicto acaba teniendo un significado mucho más trascendental. Se trata de una lucha a muerte entre el destino y la libertad (eje horizontal central de la gráfica). El destino representado por su condición fáctica: social y familiar (Mitwelt). Y la libertad, expresada en su posición rebelde y revolucionaria (Eigenwelt). Ambas acaban desplazándose al ámbito de lo corporal (Umwelt), donde ella cree poder ejercer un control a través de la comida: "La fatalidad me quiso obesa y fuerte, pero yo quiero ser estilizada y delicada”

\section{El Fondo Depresivo y Suicida de la Anorexia en Ellen West}

En este contexto la anorexia se presenta como la solución: a través de la restricción de los alimentos; dejando de comer, la anoréxica reduce al máximo los riesgos de la carnalidad. El ayuno voluntario con sus efectos de emaciación sobre el cuerpo la sustrae al deseo de los demás y le otorga, al mismo tiempo, la fantasía del dominio sobre sí misma. Su motivación es la de espiritualizar el cuerpo, negando su dimensión carnal.

La pérdida de peso tiene un sentido distinto que el de la esbeltez. El más evidente es la delgadez: las anoréxicas no pretenden ser esbeltas, sino delgadas, hasta el punto de parecer descarnadas. La anoréxica percibe la carne, la carne femenina, como impuesta por el mundo exterior y, en los casos extremos, como algo degenerado, sucio y desagradable. (McLeod, 1981, p. 137).

La anorexia es el síntoma que traduce por excelencia la negación de la corporalidad, que postula el ascetismo. El asceta renuncia a escuchar sus propias necesidades y deseos para guiarse exclusivamente por normas o ideales externos, como el buen soldado que tiene un elevado motivo por el que morir, pero ninguno por el que vivir. Renegando de su corporalidad dimite de su humanidad; pero esto no le perturba, al contrario, le conforta y confirma: siendo un ser casi espiritual, ha alcanzado un plano superior. El ascetismo se convierte así en una forma de narcisismo meritocrático (Villegas y Mallor, 2012) que combina dos elementos: el desprecio del mundo y la certeza de la elección divina.

La respuesta a la importancia que podía tener para Ellen la espiritualidad o incorporeidad debería ser descubierta en interacción con la dialéctica de su existencia personal. Podría tener algo que ver, probablemente, con su deseo de absoluto: "aut Caesar aut nihil”, que era su lema de juventud: "ser como César, o nada”. O con su fantasía de muerte prematura, como señal de elección divina: "los favoritos de los dioses mueren jóvenes”. Podría reducirse probablemente, en última instancia, al deseo universal de todo existente de llegar a ser un ser-en-si-para-si, en una imposible autoposesión total y absoluta, para evitar llegar un ser para-los-demás, 
Figura 2

Macroestructura del Discurso de Ellen West

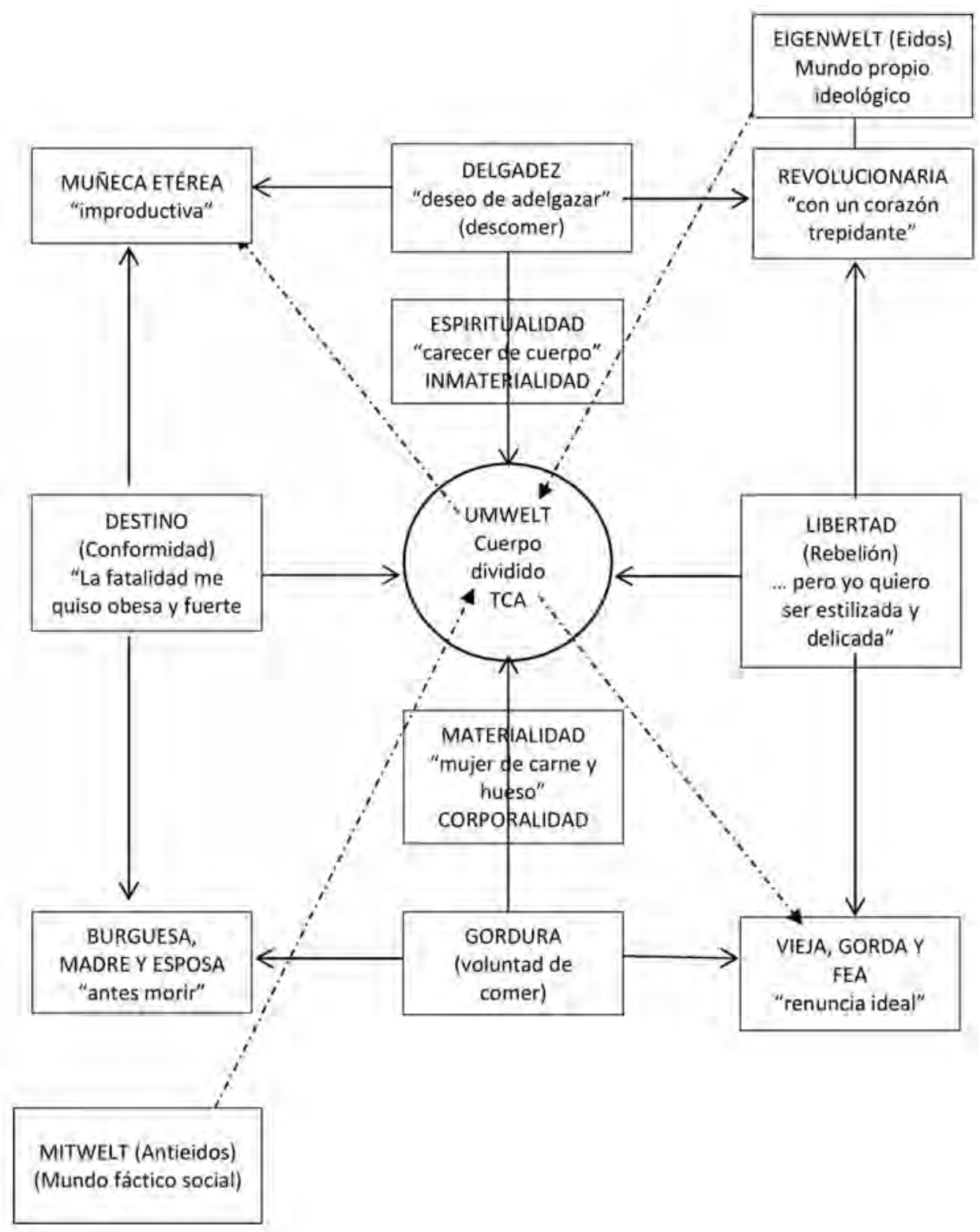

un objeto de su deseo o de su control.

Por el contrario, al fin de sus días, Ellen West fue cediendo cada vez más el control de su existencia a los demás, mientras se dedicaba obsesivamente a controlar los alimentos que ingería y los laxantes que había que tomar después. Esta 
compulsión anuló en ella cualquier otro ámbito de interés e iniciativa. Su rebelión iba dirigida contra cualquier forma de control, si bien terminó dependiendo totalmente del entorno hasta que se suicidó a los 33 años, último acto de afirmación e independencia.

Parafraseando aquel dicho popular de Ellen West podría decirse que: "entre todos la mataron y ella sola se murió” (Lester, 1971). No la mataron la anorexia, ni los ayunos, ni los laxantes, ni las caminatas extenuantes, ni la mortífera combinación de morfina y "Luminal" (fenobarbital), sino la depresión (Lang, 1987). Una depresión originada por un fracaso en la proyección del propio yo, reducido a su dimensión o apariencia corporal:

Como mi único criterio de acción era averiguar si una cosa me engordaba o adelgazaba, pronto perdieron las cosas su significado intrinseco. Ya nada me interesaba. Mis pensamientos estaban fijados únicamente en mi cuerpo, en mi comida, en mis laxantes. Mi interior estaba tan intimamente fusionado con mi cuerpo, que ambos formaban una sola unidad, constituyendo juntos mi yo individual, nervioso e ilógico.

Cuando el cuerpo demostró su incapacidad para resolver el dilema existencial planteado por la aporía a la que había llegado el conflicto entre su mundo ideal, configurado en términos revolucionarios, como expresión de su espíritu rebelde y libre, y el mundo social y familiar burgués en el que fue absorbido al contraer matrimonio con su primo Karl, cesó en su estéril lucha y se autoinmoló. Esta es la alternativa que Ellen West escogió, fiel a su narcisismo, antes de volverse "vieja, gorda y fea".

\section{Mitwelt}

\section{Eco, La Ninfa Sin Voz Propia}

Eco, nombre metafórico otorgado a una paciente de 46 años, llega a terapia de grupo con un diagnóstico de “depresión mayor recurrente”, por el que ha obtenido un grado de invalidez total (100\%), que le da derecho a la percepción de una pensión y con un historial de tres ingresos de urgencia en hospital psiquiátrico por otros tantos intentos de suicidio. Durante años ha estado hipermedicada, probando varios cócteles de psicofármacos, hasta doce pastillas distintas diarias, sin hallar mejora, sino más bien una acumulación de interminables efectos secundarios consecutivos.

Acude inicialmente al grupo con una clara actitud reticente, a causa de una mala experiencia en otra terapia grupal anterior, que define como sectaria. La terapeuta del grupo la confrontó, etiquetándola de misteriosa, por su inhibición en hablar o participar, ante lo cual Eco se levantó y abandonó la sesión. Su psicólogo individual la convenció para probar en otro grupo.

El mundo de Eco es un mundo de relaciones. Ella se constituye y se define por sus relaciones (nieta, hija, hermana, tía, prima, amiga, esposa, nuera, cuñada, secretaria, colega...). Por eso su depresión está relacionada con la disolución pro- 
gresiva del Mitwelt (el mundo de las relaciones con los demás). La muerte social, equivale para ella a la muerte ontológica. De ahí los sucesivos intentos de suicidio. No basta con ir superando las distintas pérdidas con sus correspondientes duelos, si no que su existencia ya no tiene sentido ni proyección una vez se ha extinguido el mundo donde se proyectaba.

Este mundo estaba formado por distintos submundos relacionales representados en la siguiente gráfica, que puede imaginarse como un sistema solar compuesto por el sol y varios planetas donde proyecta su luz, o como en el sueño de José, recogido en el capítulo 37 del Génesis, en el que mientras él y sus hermanos están segando en el campo, su gavilla se erige en el medio y las de sus hermanos se colocan en círculo a su alrededor para reverenciarle.

Un primer submundo, que podemos denominar familiar, está formado por la familia nuclear: padres, hermanos, abuelos, tíos, primos y sobrinos, a los que habrá que añadir más tarde suegros y cuñadas que se irán desgajando progresivamente del núcleo central a causa de muertes o alejamientos, hasta desaparecer casi por completo. El segundo por el mundo social (vecindario, estamentos profesionales y comerciales) y cultural de su ciudad natal, una pequeña ciudad del Pirineo central, con un glorioso pasado histórico. El tercero por el mundo laboral, particularmente importante en su juventud, hasta los treinta años, donde sufrió durante el primer año una situación de acoso sexual por parte de su jefe inmediato. El cuarto por la pareja con quien se irá a vivir lejos de su ciudad natal, cuyo matrimonio terminará en divorcio. El quinto, por las amistades, algunas provenientes de la infancia o del colegio, otras iniciadas más tarde, ya en la vida laboral.

En la figura 3 no sólo se reproduce el sistema relacional de Eco, formado por los distintos submundos o satélites, descritos hasta ahora, que giran a su alrededor, sino también el orden cronológico en que cada uno de estos submundos o algunos de sus miembros van desapareciendo, hasta dejarla sola con la sensación de vacío o aislamiento existencial, en el que repetidamente se harán presentes ideas e intentos fracasados de suicidio.

Figura 3

El Mundo Relacional de Eco

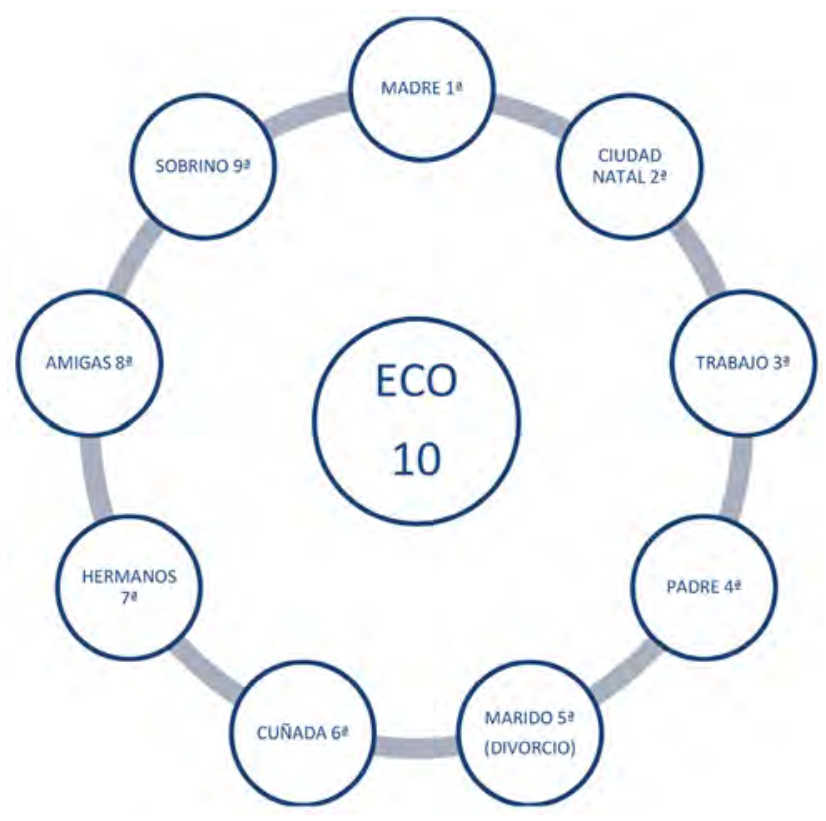




\section{Orígenes e Infancia}

Eco pertenece a aquel grupo de personas que son “hijas de la vida”; que por las circunstancias que rodearon a su embarazo, no deberían haber nacido, ni siquiera haber sido concebidas y a las que, además, sus padres o familiares próximos ya se encargaron de comunicárselo oportuna o inoportunamente. Ella es “un aborto”; nacida de rebote; su madre quedó embarazada de ella cuando su hermano de seis meses todavía estaba mamando. Nadie quería que naciera, excepto su madre, aunque al principio la vivió como una carga. Su abuela paterna, en este caso la suegra, le dijo claramente a su madre que "la niña tenía que morir, que cualquier día la encontrarían muerta en la cama”. Y efectivamente, había nacido muy pequeña y estuvo casi a punto de perecer; luego contrajo el tifus y estuvo muy enferma; pero su pediatra se empeñó en que tenía que sobrevivir y a fe que lo consiguió. Aunque de complexión delgada, en la actualidad goza de buena salud, mide aproximadamente un metro sesenta y seis, y muestra un desarrollo armónico desde el punto de vista físico, viste con gusto y, a pesar de su estado, cuida su aspecto externo: "Yo siempre tengo buen aspecto. Me esfuerzo mucho por mí y sobre todo de cara a los demás... El día que dejé de pintarme las pestañas, acabé en el hospital".

Es la segunda de tres hermanos, ella de 46 años en el momento del inicio de la terapia; el mayor, Diego, de 47 y el menor, Miguel, de 41. De pequeños vivían en casa de los abuelos paternos. No llegó a conocer a sus abuelos maternos, puesto que murieron cuando su madre era todavía una niña. Los padres de Eco fallecieron con anterioridad a su ingreso en el grupo (2010): su madre en 1987 y su padre el 2004 (figura 4).

Figura 4

Genograma Eco (realizado en 2010)

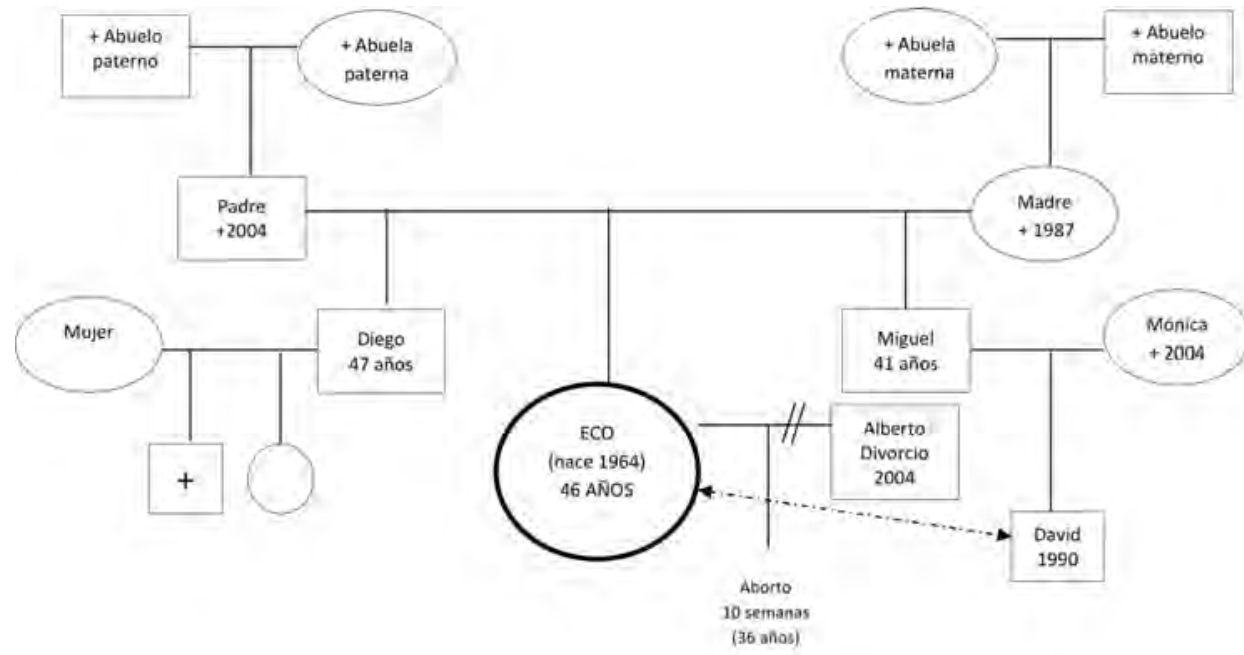




\section{La Formación de una Red Social}

Eco interpreta que ya desde su tierna infancia supo atraerse la benevolencia de los demás, sobre todo los mayores, a causa de su comportamiento servicial, responsable y complaciente. En el ambiente familiar, sin embargo, su comportamiento era más bien retraído, puesto que notaba una actitud de rechazo en contraposición a sus hermanos, que eran preferidos por la abuela y los tíos, mientras que el padre mostraba preferencia por el mayor y la madre por el menor de los hermanos. El abuelo paterno, en cambio, era mucho más cariñoso con ella, pero no tomaba iniciativas al margen de las decisiones de la abuela. Los padres estaban ocupados en su trabajo o en el cuidado de la casa o de los abuelos paternos con quienes convivían. Los abuelos maternos, como se ha comentado anteriormente, habían muerto mucho antes de que ella naciera, por lo que no llegó a conocerlos.

Con esa actitud de niña responsable se hizo cargo de su hermano menor, ya desde pequeño; le hacía compañía hasta que se dormía por las noches y se lo llevaba a jugar con sus amigas para que no se quedara solo en casa. Las relaciones con el hermano mayor, con el que se llevan solo quince meses, por el contrario, eran muy conflictivas: él le tenía unos celos descontrolados, había intentado ahogarla en la cuna, más adelante la acorralaba, la amenazaba, la había mordido, le había clavado un lápiz en la frente; ella se defendía a arañazos. La relación todavía empeoró más al contraer éste matrimonio, a causa de la cuñada que mantenía con ella una actitud claramente hostil, hasta el punto de no dejarle nunca tomar a la niña, la hija de ellos, en sus brazos. Para ella este hermano está muerto; no lo nombra casi nunca y evita hasta pronunciar su nombre. Si habla de su hermano lo hace en singular, refiriéndose siempre a Miguel, el pequeño, con quien tuvo esta relación maternal durante muchos años, al igual que más tarde con su sobrino, David, el hijo de éste (señalado con una flecha de guioncitos en el genograma, figura 4).

Los padres se ocuparon poco de ella, puesto que veían que se espabilaba sola. Si lloraba, lo atribuían a que "tenía una esponja en el pescuezo". La madre le enseñó a leer desde muy pequeña, con tres o cuatro años, de modo que cuando ingresó en la escuela ya sabía leer y las cuatro reglas aritméticas. Sin embargo, ella se sentía desamparada y llegó a desarrollar terrores nocturnos, como forma de expresar sus miedos, y aun ahora habla en voz alta por las noches y tiene pesadillas con frecuencia. Con el tiempo las relaciones con la madre fueron evolucionando, llegando a convertirse en "amigas" confidentes. A medida que iba creciendo, el padre fue adquiriendo un papel cada vez más protector hacia ella; como cuando intervino para que se cortara en seco una situación de acoso sexual, que Eco sufrió por parte de su jefe inmediato en el inicio de su vida laboral. Siempre la aconsejó y la apoyó discretamente en todo. Algunos años antes de morir, preocupado por cómo iba evolucionando su matrimonio, mostró un interés especial por ella, llamándola casi cada día y reconociéndola como la más inteligente de los hermanos, razón por la cual no entendía que se dejara comer por su marido en una relación de dominio / sumisión, aunque murió creyendo que todavía tenía arreglo su matrimonio. A su 
muerte, Eco se sintió literalmente “desamparada”.

Desde su perspectiva actual, el hecho de ser la mediana a quien nadie hacía caso, la hizo espabilar, sacar recursos para atraer la atención de los demás y convertirse en la reina de la fiesta en sociedad y en el trabajo. Tal vez por ello, Eco, construyó un imperio relacional con las amigas, ya en el colegio de monjas, los compañeros del trabajo, los vecinos, los profesores, la gente de la calle, hasta el punto de que su madre le había dicho “a ti las amistades te matarán o te salvarán”. Desarrolló el arte de hacerse necesaria para los demás, sustituyendo el mundo familiar por el social, dado que no podía confiar en el primero.

Una muestra de ello la constituye su posición en el trabajo. Ya de joven, con dieciocho años entró a trabajar en un banco. Enseguida pasó a ocupar un puesto de secretaria de relaciones humanas, lo que la situó en la encrucijada de todos los problemas del personal de la empresa, que la utilizaban como “paño de lágrimas”, piensa ella a causa de su gran capacidad de escucha empática. Los empleados del banco acudían a recursos humanos para hablar de sus problemas laborales, pero terminaban compartiendo con ella sus problemas personales, hasta el punto de que, a pesar de su juventud, se veía actuando más de psicóloga que de secretaria. El difícil manejo de la empatía le llevaba a implicarse emocionalmente con sus colegas del banco, llegando a padecer problemas de insomnio y momentos de angustia a causa del impacto que las historias de sus compañeros causaban en ella. Después de ocho años de ocupar este cargo, tuvo que pedir el traslado por indicación médica, pues entraba en colapso.

Eco (E).: Estuve en este cargo más de ocho años. Y encima, cuando murió mi madre (a mis 23 años), lo pasé muy mal y llegó un punto en el que yo ya confundía las cosas. No sabía diferenciar entre mis problemas y los de los otros. Cuando salía del banco me iba con los problemas de doscientas cincuenta personas encima. Para mí era muy duro, y tuve que pedir que me sacaran de allí.

Terapeuta (T).: Te implicas mucho emocionalmente y eso te hace sufrir. Porque tú simpatizas, no empatizas, o sea...

E.: Yo ya no sé lo que hago; llega un punto en que confundo... Me pongo en el lugar del otro... Y esto es lo que me hace daño, claro...

T.: una cosa es comprender lo que le pasa al otro y otra cosa es meterse en su piel y sentir lo que siente la otra persona. Eso no es empatizar, es simpatizar.

Estas mismas actitudes se reproducen (o transfieren) en el grupo de terapia, donde enumera una serie de compañeros, hasta cuatro, con los que se ha sentido identificada.

E.: Sí, sí, sí... y esto me perjudica mucho. Quiero decir, porque no me pasa solo aqui; me pasa con otra gente que conozco, con amistades, me pongo a llorar con sus historias, porque se me escapan las lágrimas. 


\section{El Mundo de las Amistades}

En ese contexto, donde era casi la única chica que ocupaba un cargo de relevancia social en los servicios centrales del banco, fue tejiendo una red de contactos sociales y de amistad, particularmente con las chicas que se iban incorporando al trabajo, que ha perdurado en el tiempo y que ha llegado hasta el momento actual de su vida, 28 años más tarde, formando una piña, el grupo de "las cinco". Algunas de estas amigas, particularmente una de ellas, ha ejercido sobre ella un papel protector, salvándola en los momentos más críticos de su vida, hasta el punto que muchos creían que eran hermanas, cumpliendo así la profecía de su madre de que las amistades (no la familia) la salvarían.

T.: En tu caso hay muchas relaciones cruzadas, y estás muy pendiente de lo que pasa en estas relaciones...

E.: Porque me afectan mucho y no quisiera que me pasase esto... este es el problema

T.: La pregunta es ¿qué hay en esto que te afecta tanto... o sea qué es lo que está en juego..., por qué significan tanto estas relaciones?

E.: Imagino que porque no tengo familia ¿no? (se emociona). Con miamiga Marta hemos crecido juntas como hermanas: cuando estaba medio muerta, ella y su marido me rescataron y me llevaron al hospital y mi amiga Pilar me vio tan fatal que vino para per estar 3 días conmigo.

T.: De alguna manera han venido a suplir la familia; pero está claro que no tienen el mismo tipo de vínculo que tendría la familia.

E.: Que una amiga que te vea mal y se desplace expresamente para cuidarte, para mí es mi familia

Entre las habilidades para tejer y mantener la red social están las estrategias de llamar a los demás, interesarse por ellos, alegrarse por sus progresos, hacer favores, mediar entre ellos, crear ocasiones de encuentro, colaborar en la organización de eventos festivos, etc. Y sobre todo una total disponibilidad para los demás.

E.: Estar allá siempre y si hay que hacer algo, pues se hace, y los demás pasando siempre por delante de ti y llamándote y diciéndote 'mira, a mí me pasa esto'y tu dando la cara por los demás, por todas partes, para solucionar los problemas, relegando los tuyos. Tapaba los míos con los de los demás. Porque para míse está convirtiendo, realmente en un problema, todo. Yo soy la gilipollas. Para mis amigas todavía soy eso. Me dicen que soy el Google de su vida.

Una de estas estrategias se pone de manifiesto en el grupo de terapia, a propósito del cumpleaños reciente de una de sus miembros a la que ella llamó para felicitar; y ante la sorpresa de ésta por el detalle, Eco hizo el siguiente comentario: E.: Yo de los aniversarios, me acuerdo muchísimo... Pero mucho, mucho; del de todo el mundo, ¿eh? ... Hay gente que se queda parada y pregunta: “¿Cómo puede ser que te acuerdes?”. No sé, me lo dices una vez, y ya me basta. Supongo que es porque considero que es importante para la persona. 


\section{La Formación de la Pareja}

En la trayectoria del recorrido vital de Eco, juega un papel muy importante, entre otros, la constitución y fracaso de su matrimonio, por lo que implicó de cambios en su vida. Lo dejó todo: familia, amistades, ciudad natal, ambiente social, trabajo para venir a vivir a Barcelona con el que había de convertirse en su esposo, dado que él tenía en la ciudad grandes oportunidades de progresar profesionalmente, mientras que ella en su ciudad de origen, no. Recordando los inicios de esta relación, Eco cuenta cómo se conocieron:

E.: En marzo, hará 20 años que lo conocí. Fue en la boda de una amiga. Era una época en que yo vivía con mi padre. Estaba feliz, me sentía libre, alegre: tenía chicos que me iban detrás; pero yo pasaba de todo. En la boda fui como la vedette. No sé por qué había una atracción tan increíble hacia mi por parte de la gente joven que habia en la fiesta. Sin hacer nada, me converti en la reina del mambo. Ya el día anterior fuimos a cenar todos los invitados a la boda entre los que estaba él; yo no hice nada especial; me limité a pasármelo bien y hablando con él le dije dónde trabajaba. El día siguiente a la boda se dedicó a buscarme. No sabía mis apellidos, pero recordó el nombre del banco donde trabajaba y me localizó por teléfono. En el banco me preguntaron qué habia hecho en la boda, porque muchos chicos preguntaban por mí; yo respondi, en broma, que "me limité" a hacer clientes, la gente venía a mí, había cola.

Uno de esos días me quedé a comer en el restaurante, estaba con otros compañeros de trabajo. No sé por qué intuí que él estaba alli en el pueblo. Tras las cortinas de la ventana vi pasar una cazadora marrón. No sé si es la intuición, pero luego supe que era él. Fuimos a cenar una noche, solos y al cabo de unas semanas me invitó a casa de un amigo en la playa. Yo no estaba enamorada, sino más bien deslumbrada: me llevaba en bandeja, ramos de flores, detalles. Se cuidó de enterarse por una compañera de la fecha de mi cumpleaños y se presentó por la tarde en la granja donde lo celebraba con mis amigas sin yo saberlo con un ramo enorme de rosas rojas; me regaló aquel mismo día unos pendientes de oro con una perla. Nunca nadie me había tratado antes con tanta atención. De esta manera me fue conquistando.

Después de un tiempo de tira y afloja, que duró unos dos años en que se encontraban los fines de semana, ella decidió dejar su familia, su trabajo, sus amistades y su ciudad natal para casarse y venirse a vivir con él a Barcelona. Ahora se plantea si realmente estaba enamorada cuando accedió a casarse o si, más bien, se dejó seducir, porque ella antes se sentía libre, "iba a su bola”, no era una persona que se planteara la pareja como una opción. Había tenido rollos, pero con chicos de fuera de su ciudad natal, nadie se había enterado. No quería compromisos. De él le gustó además de su atractivo físico, era alto, metro noventa, rubio, ojos verdes y fuerte, "un armario", aunque no era su tipo, que se mostrara cariñoso y detallista con ella. 


\title{
Crisis y Separación de la Pareja
}

Las muestras de cariño o afecto se fueron diluyendo progresivamente ya desde el principio de casados. Incluso él se fue descuidando físicamente. Los detalles en forma de regalos, sorpresas, etc., duraron más tiempo.

E.: Posiblemente influido por su madre, dado que, desde que nos casamos, yo no trabajaba y no aportaba económicamente nada a la economía doméstica, fue restringiendo no solo sus regalos, sino también mi libertad para disponer del dinero o comprarme cosas. Y así me fui creyendo poco a poco que todo lo que yo hacía estaba mal. Este fue el principio del fin. T.: ¿Y ese cambio cómo fue?

E.: O me engañó mucho, o es que ya era así... Su tía me dijo un día que antes ya era así, que cuando me conoció hizo un cambio. Aquel cambio duró un tiempo y después volvió a su origen. Que yo no lo conocía, claro. Porque yo había conocido otra persona. Fue él quien me vino a buscar, no yo... Alberto cuando conseguía algo, le costase lo que le costase, una vez lo tenía, lo desechaba. Y actuaba así con todo con las personas, con los coches, con todo. Era todo una ilusión enorme, pero en cuanto lo conseguía, ya estaba, ya perdía la gracia. A por otra cosa. Ya tengo el juguete, lo tiro o lo arrincono, ya no me sirve... Como los críos.

Según él, me había querido mucho. Ahora ya no me importa, ahora me da igual, pero hasta que no he llegado a este punto de no acordarme de él, me ha costado muchísimo. Bueno, llegué a decirle que preferiría poder llevarle flores a la tumba, que vivir así. Y no le deseo la muerte a nadie, pero bueno, en aquel momento, sí. Simbólicamente para mí habría sido mejor que se muriera, porque yo estaba pasando un duelo muy largo y eterno y encima continuaba viéndolo. Para mí aquello era muy duro.

\begin{abstract}
Aborto
Hacia el quinto año de matrimonio, la pareja se plantea tener un hijo. Según la opinión del ginecólogo, Eco podía tener dificultades en quedar embarazada a causa de una endometriosis, pero no imposibilitada, puesto que sus trompas no estaban afectadas. En efecto, no tuvo problema en quedar rápidamente embarazada al poco tiempo, aunque el proceso se vio interrumpido a los dos meses y medio de embarazo a causa de un aborto espontáneo. Esta pérdida fue vivida como la muerte de un recién nacido, llegando a desarrollar una depresión postparto y ser ingresada en el hospital, donde explica que hasta el celador se dio cuenta de lo derrotada que estaba e intentaba animarla haciéndola correr con el carrito por los pasillos del hospital.

E.: Hasta aquel momento estábamos bien y a mí me hacía ilusión tener un hijo. Pero ahí empezó a torcerse la cosa, porque a partir de esta experiencia empecé a cogerle pánico a las relaciones sexuales, a volver a quedarme embarazada, por miedo a perderlo, a volver a pasar por todo esto, otra vez. Me alejaba y me mostraba cada vez más reacia a todo
\end{abstract}


contacto sexual, cosa que él me recriminaba con frecuencia... Pero el problema que tenía conmigo es que él me continuaba viendo monísima, guapísima, pero yo ponía el freno, yo no quería acostarme con él... Esta era mi forma de castigarlo. Como yo me sentía anulada, me sentía mala, la forma que tenía de defenderme o de rechazarlo, pero es que tampoco me apetecía ¿eh? Si estás mal con una persona, ¿qué quieres que te diga? Al menos a mí no me apetecía irme a la cama con él...

\section{Infidelidad}

Sea por esta u otras razones, él se fue relacionando con otras mujeres. Tenía otra, una compañera de trabajo. Eco lo descubrió, al cabo de diez años de matrimonio, porque él se dejó un mensaje abierto en el teléfono. Descubrir la infidelidad fue el motivo de la ruptura, "lo eché de mi habitación y después de casa (me quedé en la casa, no volví a mi ciudad natal), pero continué dependiendo emocionalmente de él'. Lo continuaba queriendo, como si estuviera obsesionada, se quedó descolocada durante dos años intentaron volver, pero finalmente en el día de su cumpleaños, él le pidió el divorcio.

E.: Necesitaba comprender, pero élno me dioninguna explicación. Tampoco lo ha explicado a nadie. Yo estoy enganchada a querer comprender. Soy como Mourinho: “¿Por qué, por qué?...” Todo esto me hizo sentir muy pequeña y no sabía cómo enfrentarme al mundo. Estaba muy desorientada, no sabía por dónde tirar ... En aquel momento (2004) todavía vivía mi padre, pero duró bien poco: murió el 14 de marzo, mi ex me pidió el divorcio dos meses más tarde, el 14 de mayo, y el día 7 de agosto murió mi cuñada (la esposa de Miguel, el hermano pequeño), la madre de mi sobrino.

$Y$ cuando mi marido, a finales de año, se fue definitivamente de casa yo ya caí en picado. El médico que me visitó me dijo: "si no encontramos a alguien que te cuide, tendré que ingresarte". Porque yo ya no valía para nada. Necesitaba a alguien que me cuidara, Sí, sí, totalmente. Yo era incapaz, no sabia qué tenia, qué me pasaba. No tiraba; no podía hacerme cargo de nada. Tomé consciencia de que no valía para nada. De que no servía para nada, que era una mierda. Y además, su madre, mi suegra, la forma en que me trató... pues acabó de darme el puntillazo... Entonces mi hermano pequeño, Miguel, me dijo: "Ven a mi casa, que yo te cuidaré". $Y$ en 15 días me repuse muchísimo, me recuperé también gracias a mi sobrino, de 12 años que tenía por aquel entonces; yo todavía alucino de lo que llegó a hacer por mi ¿no?

\section{A Quien Dios No Da Hijos... David, el Sobrino Ahijado}

Otra relación de gran significación en la vida de Eco es, precisamente, la de su sobrino, David. Este vínculo se establece ya desde el momento de su concepción. Su madre, Mónica, quedó embarazada muy joven, a los 19 años, de Miguel, el 
hermano pequeño de Eco, que solo tenía 20. De inmediato Eco, que en la ocasión tenía 25 años, se vio implicada en este proceso. La primera cuestión que les planteó a su hermano y su futura cuñada es si deseaban al hijo o no. La respuesta está en el nombre que le pusieron al niño: David, “el deseado”. A partir de ahí se hizo cargo de todo, desde apoyar a su hermano y cuñada, a la que incluso acompañaba a las pruebas médicas, a hacer las ecografías y a comprar vestidos de embarazada o ropita para la cuna, hasta mediar en la comunicación con los padres, asistirla en el parto, ayudarla en la crianza. "Yo no podría querer más a un hijo mío que lo que he querido a mi sobrino David".

Más adelante le hizo de madre hasta el punto que mucha gente se pensaba que lo era, en lugar de tía. Cuando esto sucedía, él no lo desmentía; pero tampoco lo confirmaba. Esta suplencia se hizo mucho más activa después que Mónica, la madre de David, con una larga historia de drogodependencia, marchara de casa dejando al niño con 6 años. Y todavía se hizo más presente desde que murió, después de ingerir la dosis de pastillas que estaba tomando en una comida donde había bebido alcohol. Con anterioridad, Mónica había intentado el suicidio tirándose por el balcón, si bien la caída fue amortiguada por el capó de un coche y no llegó a matarse, pero quedó muy destrozada. En aquella ocasión había hecho explícita su intención de suicidarse, dejando escritas cartas a su hijo, David, a su esposo Miguel y a su familia.

Este sobrino tenía una relación muy afectiva con su tía, hasta el punto que Eco acudía muchas veces a visitarlo de sorpresa, para poder sentir la alegría y el afecto del chico al lanzarse a su cuello y abrazarla. Hasta en los regalos, David valoraba más la sorpresa que el regalo mismo. Miguel, su hermano, el padre de David, con frecuencia le pedía que volviera al pueblo para ayudar emocionalmente al chico, hablar con los profesores, ayudarle en los aprendizajes, etc., y ella actuaba como madrina que asume el rol de madre en ausencia o deficiencia de ésta.

Sin embargo, esta relación tan afectuosa y satisfactoria para Eco, se ha diluido estos dos últimos años, desde que David, cumplidos los dieciocho se vino a Barcelona a estudiar en la Universidad y últimamente se ha ido a Finlandia para hacer un Erasmus. Ya no le llama, ya no se lanza afectuoso en sus brazos, ya no la lleva con su grupo de amigos, ni la incluye en su página de Facebook. Se ha esfumado, tal vez porque su tía, al intentar suicidarse repetidamente, le ha fallado como le falló su madre; ha dejado de ser un punto fuerte donde apoyarse. Y como le dijo David a propósito de la muerte de su madre: "es inútil darle vueltas, ya no se puede hacer nada".

\section{Ocaso y Disolución de un Mundo de Relaciones}

La historia de Eco es la de la construcción un castillo de naipes que se monta pacientemente, pero que luego se desploma inexorablemente en un instante con un soplo, o la de una telaraña que se teje con cuidado, pero que se destruye de un escobazo. El mundo relacional descrito en la gráfica inicial ya incluye el orden 
en que sucesivamente va apagándose los satélites que reflejaban su luz a causa de muertes, abandonos, pérdidas, separaciones, alejamientos. Una historia de duelos acumulados con los que llega a terapia, después de tres intentos de suicidio.

\section{La Familia Se Desmorona}

La primera de las pérdidas es la de su madre, que murió tempranamente en 1987. Eco lo cuenta con sus propias palabras:

Mi madre faltó cuando todos éramos muy jóvenes. Yo tenía 23 años, mi hermano mayor, Diego, uno más que yo, 24 y el menor, Miguel, tenía 18 recién cumplidos. El mayor, estaba estudiando en Barcelona, y Miguel y yo continuábamos en el pueblo. Miguel no quiso de ningún modo bajar a estudiar a Barcelona para no dejarme a mi sola con mi padre, que encima estaba enfermo. Es que era un drama lo que había en mi casa. Y ni mi tía, ni mis primas... allí no se acercaba nadie, no se acercaba ni Dios. Ni preguntaban si nos hacía falta algo. Mi padre no se podía levantar de la cama. Había que llevarlo días alternos a curarlo al hospital.

Cuando se murió mi madre, todos pensaban que era mi padre, quien había muerto. Eso fue el mes de febrero y mi padre estuvo un mes y medio ingresado en el hospital. Tuvo una diverticulitis, con dos operaciones a vida o muerte. La segunda vez no lo pudieron cerrar. El estómago era una llaga. En un año llevaba tres operaciones. En agosto lo tuvieron que volver a operar para reconstruirle todo el intestino, y ponerle una malla, y todo eso lo vivimos nosotros. Mi hermano mayor, no. Eso lo vivimos Miguel y yo. Miguel se pasó todo el verano, bueno, todo el tiempo que mi padre estuvo ingresado, en el hospital, estudiando la asignatura que le quedó de COU, para poder examinarse en septiembre. Porque yo trabajaba, falté un montón de días al trabajo ese año, y me lo quitaron de vacaciones. Mi padre estuvo nueve horas en el quirófano. Nos dijeron: "despediros porque no sabemos si saldrá”. A los tres días de salir mi padre del hospital, se murió mi mejor amiga, y a los quince días se murió mi madre. ¿Cómo se come eso? Se te junta todo, es muy duro.

Además, te quedas solo, tres personas en un piso. Un chico de 18 años, cuando tú cada día a las 8 de la mañana tienes que irte a trabajar, y lo dejas con tu padre enfermo. ¡Y suerte tuvimos de la vecina! Y encima, la vecina me cuenta que mi tía le dijo, que sobre todo cuidásemos mucho a mi padre. Y que ella fuese a comprar a la tienda de abajo y que no subiese para ver a su hermano.

Entre medio de la muerte de la madre (1987) y la del padre (2004), Eco se casó con Alberto con el consiguiente abandono de su ciudad natal, alejamiento de la familia y de las amistades y pérdida del trabajo, que nunca más recuperó, aunque hizo algunas breves incursiones como dependienta en tiendas de ropa o de diseño gráfico. Todas esas pérdidas personales, profesionales, relacionales y proyectuales 
hay que cargarlas en el saldo negativo de sus cuentas vivenciales.

Al poco de la muerte del padre (2004) se produjo la ruptura definitiva de su matrimonio con la obtención del divorcio. Eco se sintió como un juguete roto, abandonada y tirada por su expareja. A estas pérdidas hay que sumar en el mismo año la muerte de su cuñada, la madre de su sobrino y ahijado, David, dos años después del intento de suicidio fallido.

Las relaciones con el hermano mayor, estaban heridas de muerte ya desde la infancia, pero las que mantenía con su hermano menor, Miguel, y su sobrino, David, se reforzaron con la muerte de la madre de éste, su cuñada Mónica. Sin embargo, los acontecimientos posteriores, a partir de los estudios universitarios de David en Barcelona y la falta de asistencia de su familia en sus intentos de suicidio, acabaron de completar el círculo de pérdidas familiares que Eco interpretó como una orfandad impuesta.

\section{Las Amistades Se Difuminan}

El mundo de las relaciones sociales y de las amistades con el tiempo fue experimentando su propia evolución y deterioro. Ya con 23 años sufrió una pérdida muy sensible, la de la muerte de su mejor amiga de infancia, de un ataque al corazón. No vio a su amiga ni muerta ni enterrada, la seguía llamando porque no aceptaba su muerte. Hasta que no visitó su tumba, no se lo creyó.

Luego, con el paso de los años, cada una de las amistades ha seguido su propio camino. Algunas se casaron y tuvieron hijos, otras no; pero se quedaron a vivir en su ciudad natal. Ella, por el contrario, a los treinta años, al casarse, se vino a vivir a Barcelona. Al cabo de un año de la separación y por la insistencia de parientes y amigos que aseguraban que la ayudarían a rehacer su vida se fue a vivir a su ciudad natal y permaneció allí 3 años, alternando varios trabajos, pero al final volvió a Barcelona, porque notaba cómo poco a poco se iba haciendo un vacío a su alrededor, porque tras diez años de ausencia, los vínculos de pertenencia ya se habían roto y no había modo de recomponerlos: había perdido su lugar en el mundo.

Algunas de estas amistades han jugado en momentos críticos un papel salvador, pero gradualmente la han ido dejando sola o, al menos, eso es de lo que se queja, puesto que nunca la llaman o tal vez se fían de que ya llamará ella y si lo hace aprovechan para explicarle sus historias, sin darle opción a que ella explique la suya. Esta característica es la que permite introducir en el diálogo terapéutico la analogía con la ninfa Eco, que resume muy bien el significado de su posición existencial en este mundo.

T.: Tú eres como un eco en quien encuentran resonancia todas las voces de los demás, pero tú careces de voz propia... Eco era la ninfa que se enamoró de Narciso, pero que se quedó sin discurso. Solo podía repetir lo que decían los otros. Cuando a ti te preguntan ¿qué tal?, ¿cómo va?” y respondes "va..." es una invitación a que hablen los demás, relegándote a ti misma al papel de eco de sus discursos. 
E.: Es que llega un momento en que ya no sabes qué decir.

T.: Pero no sabes qué decir, porque ¿no tienes un discurso propio? o porque ¿no sabes cómo lo van a recibir los demás?, ¿qué reacción va a provocar en ellos? Por ejemplo, con tu sobrino ya no sabes qué decir, porque no sabes cómo reaccionará. No porque no tengas nada que decir, sino que no te atreves. Porque si reacciona de una forma despectiva, o pasa de ti, no te hace caso, acabas sin hablar, te quedas muda, sin voz. Los demás tienen el poder de quitarte la voz. ¿Cómo es que tienen este poder?

E.: A veces me da miedo explicar lo mío... A mí nadie me ha preguntado por qué me ha pasado lo que me ha pasado.

T.: Nosotros querríamos preguntártelo, ¿cómo es que llegaste a este punto? E.: Porque tenía la sensación de que no tenía nada, no tenía nada por lo que luchar, no sabia encontrar un camino, no sabia qué estaba haciendo aquísi realmente quería hacer algo, llegar a alguna parte. Estaba cansada. Una acumulación de muchos años y de muchas cosas.

T.: Una acumulación y una consecuencia de muchas cosas.

\section{Los Intentos de Suicidio}

En ese contexto existencial se comprende el surgimiento de la depresión y el planteamiento del suicidio. La depresión responde al hundimiento de un mundo. Cuando el suelo se hunde bajo tus pies, no puedes ya sostenerte y te caes. Las fuerzas te abandonan, porque solo pueden ejercitarse con el apoyo de un centro de gravedad. Sin él, todo se vuelve etéreo y huidizo, nada tiene peso ni sustancia.

El mundo de Eco es un mundo de relaciones. Eco existe en el pour autrui (en la relación con el otro), como diría Sartre, que distingue entre el "être pour soi” y el "être pour autrui”: ser para sí mismo o ser para el otro. Cuando ese otro desaparece, yo dejo de existir y si dejo de existir ya me puedo morir. El suicidio aparece como una consecuencia lógica.

Los intentos de suicidio se perpetraron en tres ocasiones. En el primero, hace dos años, estuvo 35 días internada en un hospital psiquiátrico. Vio mucha gente muy mal allí dentro. Esa época la recuerda muy negativa pues no iba a visitarla nadie, ni siquiera sus hermanos o su sobrino David, a quien tanto había cuidado. La dejaron tirada y le dijeron que si estaba en el hospital era porque ella lo había querido así. Al salir fue a vivir con una tía suya en un pueblo de la costa, pero cuando volvió a su casa, recayó de inmediato y la ingresaron de nuevo en el psiquiátrico. Allí encontró una amiga que había hecho en su primer ingreso. Recuerda que ella y su amiga, los días de visita, se sentaban solas en una mesa del bar del hospital, esperando inútilmente que alguien viniera a verlas.

El tercer y último ingreso lo sufrió 7 meses antes de iniciar el grupo de terapia, en agosto 2009. Cuando salió del hospital esta última vez, se prometió a sí misma que no la volverían a ingresar nunca más, pues lo había pasado muy mal. Fue una experiencia muy dura. 
E.: Llegó un punto en que yo ya no quería vivir. Mi vida ya no tenía sentido. Yo perdí el norte totalmente, el sentido del amor, de todo. O sea. . . sentía en mi interior que ni yo misma tenía sentimientos, ni los demás los tenían hacia mí, pero es que tampoco me sentía capaz de tener sentimientos. Estaba como muerta por dentro. Nada me importaba. A veces me doy miedo. Estaba bloqueada, no podía ni llorar... Ahora lloro, reacciono a las cosas llorando, pero en aquel entonces no podía. Era el fruto de muchas cosas, de muchos años atrás. Pienso que había un bloqueo de tantas cosas, un cúmulo de mil cosas. Yo era como la columna que lo sostenía todo, a la que se le podía apalear y se lo tragaba todo. Pero luego eso se enquista y se te queda ahi metido... No me quejaba de que yo hubiera dado mucho, si no de que no viniera nadie a verme "¿por qué no vienen? ¿Por qué no están aquí conmigo?". Para llegar a la conclusión: "esto es que no me quieren", no que yo había querido mucho y que habia dado mucho. Esto no lo pensaba, sino que no me quería nadie.

T.: Bueno, pero tal vez el concepto de amar sí que lo tenías en función de dar y recibir.

E.: Si, pero de dar cariño, dar besos y abrazos, y de mostrar constantemente que estás queriendo aquellas personas.

T.: Y en los momentos en que tú sentías que necesitabas que alguien estuviera a tu lado o simplemente te apoyara y no lo ha hecho, ¿qué sentías? E.: Pena. Pena hacia mí misma. Rabia, no; pena. Sencillamente la lectura de que tú estás implorando desesperadamente y no sepan darte un abrazo; esto no puedo entenderlo. Yo si veo a alguien llorando desesperadamente no puedo dejar de acogerlo y abrazarlo, aunque no sepa o no quiera decir lo que le pasa, que no está capacitado en aquel momento para explicar lo que le pasa... pero aquella persona necesita un consuelo; necesita alguien a su lado, alguien que le dé la mano, que le abrace, que sepa que no está sola... Entonces yo lo único que pido es que alguien me quiera por lo que soy, no por lo que hago.

T.: Tú lo que necesitas es que la gente te quiera por lo que eres, no por lo que haces. Pero en el momento en que detectas que nadie te quiere por lo que eres, en aquel momento...

E.: ... pasan estas cosas (en referencia a los intentos de suicidio) ... Más claro...

T.: Ya, por tanto, quiere decir que hay un punto en que necesitas a los demás.

E.: Evidentemente necesito a los demás, por eso tengo amistades y siempre las he necesitado. Ya desde pequeña buscaba en casa de los vecinos, porque estaba siempre de puerta en puerta. ¿Qué buscaba, cariño, compañía? Algo buscaba, porque si no, no me habría puesto enferma cuando tuve que irme de aquella casa.

T.: Visto desde ahora, ¿qué crees que buscabas? 
E.: Supongo que buscaba cariño, que me hiciesen caso... Hay una cosa que me llama la atención. Ya en la adolescencia en un juego entre amigos, varios de ellos coincidieron en escribir, en secreto y por separado, sobre mí: "que amaba demasiado". Con el tiempo aquel juego me ha hecho pensar que ya en aquella edad, con catorce o quince años, habia personas que se daban cuenta de que daba más de lo que podía dar.

T.: Eso es. Entonces, ¿crees que podríamos empezar a intentar entender todo esto?

E.: Deberíamos, porque si no me moriré, y nada habrá tenido sentido...

$\mathrm{Si}$ ahora Eco viene a terapia es porque después del tercer intento tocó fondo: nadie acudió en su auxilio. Entendió que estaba sola y que tenía que hacerse cargo de su vida.

\section{Falta de Amor Ontológico y Narcisismo}

Eco carece de entidad, no tiene voz ni discurso propios, se limita a reflejar la de los otros. Se enamora de Narciso que solo se ve a sí mismo y, rechazada por él, se refugia en la penumbra de una cueva, donde languidece hasta morir. Este dejarse morir es el equivalente del suicidio.

Los intentos de suicidio (siempre con pastillas), Eco los vivió como un dormir, sentía paz, y cree haber encontrado la energía de sus muertos. "La muerte es como si te pusieras a dormir, por eso no te preocupa. Cuando uno intenta suicidarse solo piensa en uno mismo, no en los demás...”.

El problema de Eco es la falta de amor ontológico. Parte de un déficit originario: "no debería haber nacido"; es "un aborto", según la abuela paterna: "cualquier día la encontrarán muerta”. No se ha sentido legitimada en su existencia, sino en la sumisión o complacencia de los demás. Cuando falta el amor ontológico, aparecen formas de narcisismo que intentan dar motivo de valor o amor a uno mismo, sustitutivas del amor originario, como el narcisismo aristocrático, meritocrático o plutocrático.

Eco, teje una red de relaciones sociales en las que se expande y refleja. Se regula socionómicamente con éxito, hasta que se van apagando uno tras otro, cada uno de los satélites a los que iluminaba. Con su reflejo, ellos confirmaban su luz. Por eso es tan importante tener donde reflejarse. La suya es una crisis del narcisismo plutocrático: "tanto tengo, tanto valgo" (Villegas y Mallor, 2012, 2015). Si no tengo alguien a quien querer, mi vida carece de sentido.

\section{El Giro Terapéutico}

El proceso terapéutico proporciona a Eco la oportunidad de aprender del gran error de su vida, que en sus propias palabras es el de haberlo dado todo, haber confiado demasiado, haber puesto su vida en manos del otro.

T.: Estabas diciendo que nadie te había preguntado sobre la separación.

E.: No recuerdo que nadie nos haya preguntado, ¿quéos ha pasado, ¿cómo 
ha sido, de dónde viene?

T.: Pues te lo preguntamos nosotros ahora, si es que todavía tiene sentido para ti.

E.: Supongo que sí, porque me sentí engañada.

T.: Te sentiste engañada, ¿de qué manera?

E.: Pues que mientras duró el noviazgo, él estaba en Barcelona, yo estaba en mi ciudad natal. Cuando yo lo dejé todo, amigos, familia, trabajo, lo hice para estar con él.

T.: Empecemos por ahí. Tú lo dejas todo por él. ¿Por qué lo haces?

E.: Porque le quiero. Sí...Pero después de me doy cuenta de que él no me quería tanto, pienso yo. La decisión de venir a vivir a Barcelona fue para no cortarle las alas a él. Él tenía muchas posibilidades de prosperar. Yo no.

T.: Había una situación de desigualdad.

E.: Exacto.

T.: En la que él tenía una posición de ventaja o privilegio.

E.: Exacto.

T.: Tú renunciabas a la tuya por la de él.

E.: Exacto.

T.: Y esto ahora como lo ves.

E.: Como una gilipollez; porque no tenía que haberlo hecho. El peso de todo recayó en mí. Si me equivocaba, no podía pedirle nada a cambio. Aquí me volvi loca. Encontré trabajos de contabilidad, pero no sabía llevarla.

T.: ¿Esa falta de apoyo fue en toda la relación, ya desde el inicio?

E.: Si.

T.: ¿Y no lo habias detectado antes?

E.: No. Este fue mi gran fallo.

T.: Entonces, ¿qué pudiste aprender de esto?

E.: ¿Qué aprendí? Que no lo supe ver. ¿Por qué no lo supe ver? Porque estaba muy ciega. No supe ver lo que se me venía encima.

T.: No te tomaste en cuenta tú misma.

E.: No. Confié demasiado. Lo di todo para no recibir nada. Como siempre. Siempre lo mismo.

T.: Eso quiere decir que tú has delegado demasiado tu poder en los demás.

E.: Me han relegado. No es que yo haya delegado, es me han relegado.

T.: Ellos te han relegado y tú has delegado. Si ahora pudieras rehacer la situación, ¿qué harías distinto?

E.: Estaría sentada en un banco en mi pueblo hablando con mis amigas. Lo tengo muy claro. Por mucho que lo hubiera querido. Es el error mayor que he hecho en mi vida y me arrepentiré siempre.

Pero no se trata solo de no volver a hacerlo, sino de aprender que esta "gran capacidad de amor o donación" en el fondo no era otra cosa que un intento de ver reverberar sus propios rayos de luz en la mirada, en la sonrisa, en la acogida, en 
el abrazo o en el deseo del otro. Es cierto que "no das para recibir" (do ut des), como reivindica repetidamente ante los compañeros del grupo, sino para reflejarse (videor, ergo sum: "soy vista, luego existo; me ven, me llaman, me tiene en cuenta, me visitan en el hospital, me desean, me necesitan; me añaden en sus contactos de facebook), y el día en que no le llega su propio reflejo se queda sin luz, oscurece y languidece, como Eco, hasta morir.

Ya en el último periodo de su terapia, Eco ha establecido una relación amorosa con un hombre casado, propietario de una cadena de supermercados, lo que le hace de nuevo consciente de su capacidad de iluminar, o más bien "deslumbrar" con su luz, que ve reflejada en el deseo sexual del otro:

E.: Bueno y todo esto me da vidilla... Y yo me siento bien, me siento como una reina... es muy importante para mí en estos momentos sentirme así ¿no? O sea, como la mejor del mundo... Y aprovechar estos momentos..., y ya está. Que luego no puede ser, pues otro duelo y volveremos a empezar. T.: Lo importante no es solo que te dé vidilla, sino que eso te haga sentir que tú tienes un valor que no necesariamente depende de que el otro te lo haga ver...

E.: No, claro...

T.: De hecho, al final el bienestar de cada uno depende de su proceso personal, de estar bien con uno mismo

E.: Per,o él me hace sentir bien, la verdad es ésta...

T.: Sí, claro, a nadie amarga un dulce...pues estupendo; pero si solamente comes dulces, enfermas de diabetes...

E.: Cuando a una persona se le iluminan los ojos, se le alegra la cara cada vez que te ve y se le dibuja una sonrisa en los labios, dices: pues, muy bien ¿no?

T.: Cierto, esto también te estimula a salir de la cueva.

E.: Esto es el que yo siempre pienso, bueno mientras él esté... pues esto es lo que a mí me da ganas de arreglarme cada día, de salir, de ir a dar una vuelta... Pero esto me ha costado un montón; pero ya está. Es que yo tampoco me daba por aludida, me hacía el longuis, pero es que también tenía mucho miedo... a que me vuelvan a hacer daño...

La regulación socionómica complaciente y vinculante, dependiente y oblativa a la vez, que ha presidido su historia ha obstaculizado el pasaje hacia la autonomía. Por suerte todavía ha podido recuperar un poco de "vidilla". Lo importante es que ésta evolucione hacia la vida, una vida a la que se le reconozca un valor propio.

\section{Eigenwelt}

\section{Heidi, la Niña que Llegó a Mujer}

Heidi, nombre metafórico aplicado a una paciente de 54 años, acude a un grupo de terapia con un cuadro de sintomatología compleja, caracterizada por reacción 
depresiva, fobia social, agorafobia y diversas formas de somatización, que en el periodo inicial de la terapia van agravándose con nuevos síntomas (fibromialgia, síndrome de hipersensibilidad química múltiple, etc.), y con la sensación subjetiva "de tener un cuerpo que la lastra, a pesar de tener la mente clara a veces, y confusa otras”. La demanda literal de la paciente en la entrevista de acogida era "dolor e insomnio", alegando síntomas físicos como dolor y fatiga; síntomas afectivos como ansiedad e irritabilidad, y “colapso" por "querer hacer más de lo que puede hacer”, refiriéndose a las limitaciones físicas, corporales, ante las "demandas mentales" de actividad.

\section{Genograma e Historia de Vida}

Heidi, originaria del norte de la península, es la mayor de dos hermanos, ella y Paco, catorce meses menor. El padre "abandonó a la novia rica de siempre en el pueblo" para casarse con la que sería la madre de Heidi, aspecto que siempre fue criticado por la abuela y madre paternas; fue un “estigma” familiar. La madre de Heidi quedó pronto embarazada de ella. Al poco tiempo, cuando Heidi tenía apenas tres años, el padre emigró a Suiza por motivos políticos y laborales, y posteriormente se le unió la madre, dejando a sus dos hijos con los abuelos maternos. Como Heidi en las montañas, creció en un medio natural durante los primeros años de su infancia: "Mi niñez es mi refugio siempre, los silencios, la no comunicación, la sensibilidad, el dolor... en éste refugio también hay dolor... Mis "nostalgias” están siempre en el pueblo en mi niñez, pero me marcaron para siempre, allí tenía tantos refugios: mis abuelos "la abuela" "el abuelo”, mi castaño, los montes, el bosque, las estrellas, los árboles. Cómo me gusta trepar a los árboles, soy la mejor, cómo me gusta; ni tan siquiera los niños me ganan $[\ldots]$

Cuando te subes a un árbol y te quedas ahí rato es impresionante cómo cambia todo, es como entrar en otro mundo: el ruido cambia, las hojas hacen música, las hormigas hacen su camino. Si estás muy quieta y calladita los pájaros se posan, o les cantas a los pájaros y les contestas y te vuelven a contestar y estableces una conversación y se vuelven a otro lugar a volar”.

Más tarde, la historia se torció; tuvo que dejar su refugio en la montaña para ir a vivir a una ciudad en el extranjero con sus padres, y quienes tenían que continuar, o mejor dicho, reemprender tras haberla abandonado, la tarea de fundamentar su existencia. En lugar de eso pervirtieron su misión, abusando sexualmente de ella. En relación a esta experiencia comentará más tarde en terapia:

"Pero sobre todo, pues te arrancan de un sitio donde todo era idílico... Porque cuando era pequeña, cuando estaba en el pueblo, era todo muy bucólico... Pero luego, aparte de eso, como estaban los abuelos, sobre todo mi abuela, que me daba tanto mimo... Es que a veces aún siento sus brazos, sus abrazos. Eso queda para siempre; ese sentir... y lo suplía todo... Todo lo que necesitaba lo tenía y no me hacía falta nada más. También era la 
edad, quizás. No te das cuenta de esa necesidad de... Estaban los abuelos, pues bueno, ya está. Ya era suficiente.

Y bueno, el que me llevaran allí, pues, fue terrible, fue extraño. Creo que dentro de su ignorancia ellos intentaron formar una familia, los cuatro, pero no supieron hacerlo, porque era desde la autoridad. Sí, era todo autoritario; había que hacer lo que decían y cómo lo decían; por eso hacíamos trastadas con mi hermano, porque teníamos que desahogarnos por algún lado”.

Durante ese tiempo de convivencia familiar en Suiza fue cuando se produjeron los abusos sexuales por parte del padre. Esta situación se prolongó durante años hasta que, al llegar a la pubertad, la situación se hizo insostenible.

"Estos ataques fueron continuos durante dos años, yo no gritaba hacia fuera, aceptaba la sumisión como un acto donde él también me hacía sentir importante, cómplice muda, era su preferida... No había otra alternativa para mí, formaba parte del momento. Esto hizo que mi comunicación con lo demás fuera errónea, debido al trauma vivido... Mi madre, cansada de encontrar la cama revuelta, cada vez que regresaba a casa, cargada con la compra del mercado, negoció con mi padre lo que sería mejor para mí”.

Así fue cómo esos padres abandonistas y dimisionarios decidieron volverla con doce años a su tierra natal e internarla en un colegio, delegando, de nuevo, la educación de la niña en manos ajenas.

Permaneció en el internado hasta la mayoría de edad, momento en que deliberadamente quedó embarazada para "huir" de aquella angustiosa situación con su novio, a la postre marido, Antonio y, una vez más, otro elemento maltratador en su vida, con quien tuvo dos hijos, Rosa, actualmente de 34, casada y con un hijo ya de 2 años (su nieto) y Ramón de 24 (discapacitado psíquico). Diecisiete años después se separan, quedándose ella con la custodia de los hijos. Profesionalmente llegó a responsable de cocina, hasta que la fibromialgia ya no le permitió seguir trabajando, obteniendo más de un $75 \%$ de invalidez. Su actividad principal, en la actualidad, es cuidar de su hijo Ramón, quien se desenvuelve razonablemente bien en el mercado laboral adaptado.

En el momento de iniciar la terapia de grupo (primavera de 2012) vive con su segunda pareja Marcos, viudo y con un hijo de un primer matrimonio, a quien califica del "amor de su vida". La relación se inició cuando la enfermedad de Heidi aún no había dado ningún síntoma, pero se hizo más estrecha a medida que la salud de Heidi fue empeorando. La primera mujer de Marcos falleció por enfermedad neurodegenerativa (esclerosis múltiple), siendo él su cuidador principal hasta el final.

En la figura 5 se reproduce el genograma de Heidi, donde aparecen las relaciones más significativas en su mundo familiar. Le acompaña el cronograma, que recoge sucintamente la secuencia de los acontecimientos vitales más importantes hasta el inicio de la terapia. 
Figura 5

Genograma de Heidi

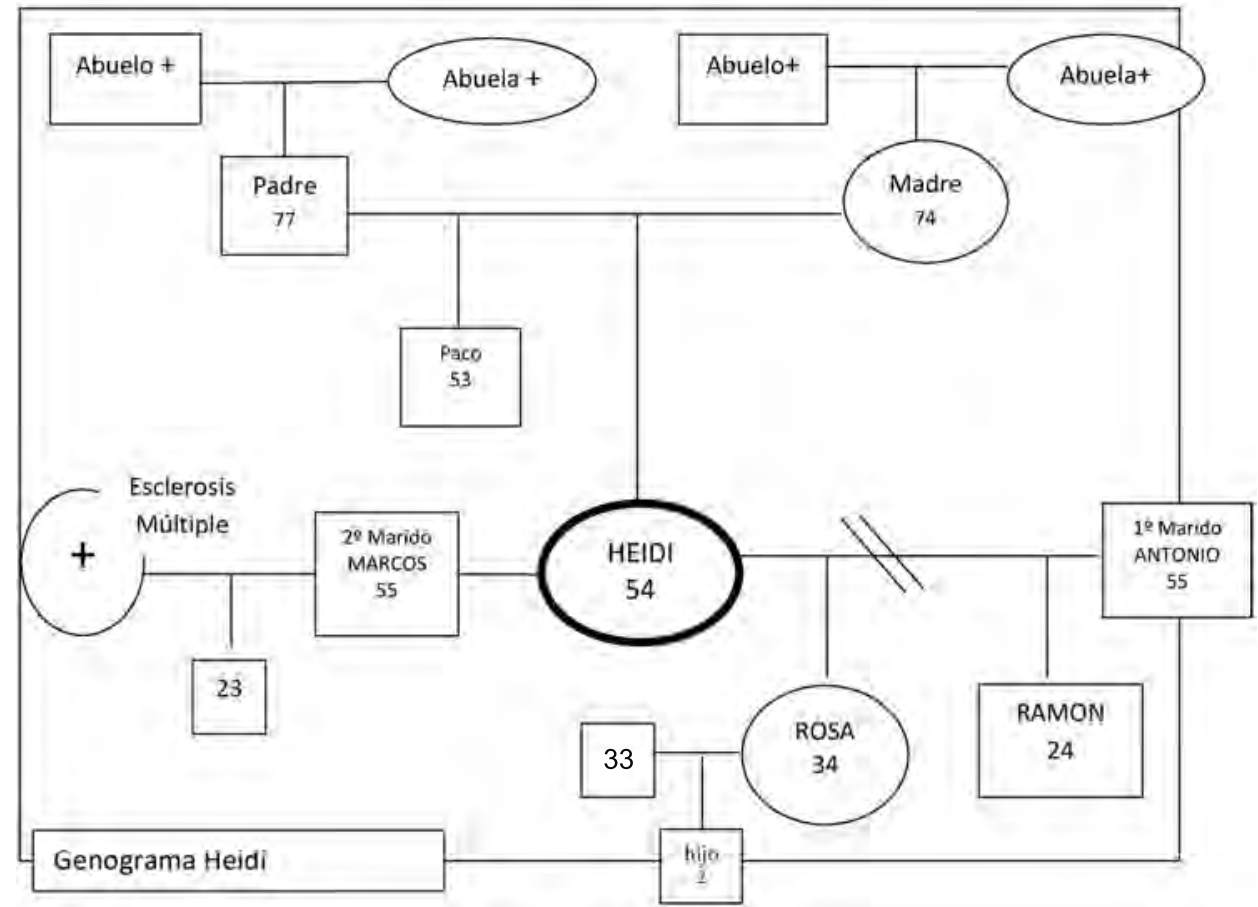

Cronograma

- 1958. Nace en un pueblo del Principado de Asturias (14 meses después nace su hermano, Paco).

- 1962 los padres emigran a Suiza y dejan a los hijos con los abuelos maternos.

- Hasta los 8 años está con sus abuelos en el pueblo.

- De los 8 a los 12 en Suiza con sus padres.

- A los 12 es enviada a un internado en Asturias donde permanece hasta los 18 mientras sus padres continúan en Suiza con el hijo, su hermano. Ella volvía cada año a Suiza para las vacaciones de Navidad y verano, hasta que marchó a Colombia.

- Alos 18 deja el internado y se va con el novio, Antonio (son casi coetáneos 7/8 meses mayor él).

- Queda embarazada de su hija a los 19.

- Se casa (1977).

- Nace Rosa (1978).

- Van a Colombia (1979/1980) (estarán 10 años). Allí trabaja en una tienda con una señora de Barcelona. Pierde el miedo al público; las clientas la adoran. 
- Nace su hijo Ramón (1988). Problemas perinatales: autismo (ahora tiene 24).

- Vuelven a España (1989/1990). El motivo fundamental es cuidar al niño.

- Se separan en el 94 (17 años casados) (El marido se va con una prima suya).

- Desde el 2005 está con una nueva pareja, Marcos (viudo, con un hijo propio). Se siente muy cuidada por él. Hace tres años conviven en Barcelona.

- Diagnosticada de agorafobia, depresión, fibromialgia, dolor crónico, invalidez 76\%, síndrome sensibilidad química múltiple. Los primeros ataques de ansiedad ya en Suiza y después en Colombia.

- A finales de marzo de 2012 inicia terapia de grupo que termina en junio 2015.

\section{El Relato Autobiográfico}

Pero dejemos que sea Heidi quien recomponga con sus propias palabras su historia de vida:

\section{Infancia y Adolescencia}

H.: Hasta los 8 años estuve con mis abuelos. Luego a los 8 me llevaron a Suiza mis padres. Y luego pues, por decisión de ellos me trajeron a España otra vez, a los 12. Tuve una infancia bastante movida.

T.: Una infancia internacional.

H.: (sonrie) Más o menos... Sí, pero bueno también me trajo, me aportó cosas nuevas... y ver otras cosas también fuera que eran tan diferentes... T.: ¿Y cómo te sentiste alli?

H.: Extraña. De repente pasar de un ambiente muy protector por parte de mis abuelos a un ambiente que para mí era hostil, extraño y hostil. Porque bueno, en todos los aspectos, nivel familiar y luego a nivel escolar...

T.: Y eso influyó para que te mandaran otra vez a España.

H.: Sí. Creo que fue un poco como un castigo. Porque no me enviaron con mis abuelos, me enviaron a un colegio interna, donde estuve hasta los 18 años.

A propósito de su estancia en Suiza, Heidi aprovecha para hablar de la calidad de la relación con su familia, padres y hermano, en ese periodo de los ocho a los doce años, después de haber pasado una infancia idílica con los abuelos maternos. En referencia a los padres comenta

H.: Yo no los conocía, es que, no había convivido casi con ellos ... y tampoco ellos se habían esforzado mucho. Entonces...

T.: ¿Con los dos, tanto con tu madre como con tu padre notabas esa falta de cariño?

H.: Sí, sí con los dos. Totalmente. No eran cariñosos... Tampoco con mi hermano

T.: ¿Y tú con tu hermano te llevas bien, tienes buena relación con él? 
H.: Mucho, mucho, mucho. Tenemos un vínculo muy fuerte. Aunque él esté alli y yo aqui... Nos queremos mucho. Nos hablamos casi cada día.

\section{Matrimonio con la Primera Pareja}

Continuando el diálogo y, a instancias de los terapeutas, Heidi retoma el tema de su matrimonio y primera pareja

T.: ¿Y luego cuando saliste del internado...?

H.: Pues... empecé a estudiar informática, en aquella época perforista. Pero bueno, le daba más importancia en aquel entonces al sentirme ya fuera del colegio. Porque al salir del colegio, te encuentras sola ... estaba en un piso compartido. Me sentía, pues algo especial... Tener dijéramos mi vida. No la sabía administrar tampoco, porque nadie me había enseñado... Tampoco tenía referencias. Y era, bueno, diversión total: y pues con el primer chico que sali, me quede embarazada de mi hija con 19 años. Mis padres hicieron todo lo posible para llevarme a Suiza, incluso para que abortara.

T.: ¿Tus padres no querían que tuvieras al niño?

H.: No, no... Más que nada por ellos, o sea por lo que dirán y por muchas cosas más. En aquel momento yo tampoco era consciente de lo que llevaba dentro. Pero sí decidí, me dejé influenciar más por parte de los padres de mi marido..., su madre sobre todo es muy religiosa, muy convencional.

T.: ¿Os casasteis?

H.: Si, mis padres nos pagaban el apartamento, yo ya no seguí estudiando, yo atendía a la niña.

T.: ¿Tú eras feliz en aquella época?

H.: Sentía que tenía algo mío que nunca había tenido..., mi hija y eso me hacía muy feliz. Porque, el depositar todo lo que anhelabas dar a alguien y no podías porque te falta cariño por parte de tus padres, de tus familiares... Porque ellos lo veían de otra manera, que lo tuvieras todo, los caprichos, que te pagaran todo, pero eso no era suficiente, me faltaba el acercamiento, no había confianza. Yo, todavía hoy, los conozco muy poco...

La historia de su matrimonio empezó, sin embargo, a torcerse desde casi ya el primer momento, terminando en separación al cabo de unos años:

T.: Estabas hablando entonces de que con 19 años habías tenido a tu niña y estabas viviendo con el padre de tu hija. ¿Cómo iba la relación con tu marido? H.: Mal; y a al empezar, cuando empezamos a vivir juntos ..., ya la primera noche fue diferente. Era una máscara lo que tenía, se quitó la máscara... T.: ¿Y cómo lo notaste, qué veías en él?

H.: (Suspira) Hechos y acciones. Violencia psíquica... Aquí mando yo y aquí soy yo, y aquí ordeno yo.

T.: ¿Y no habias notado nada de estos rasgos antes?

H.: No, yo estaba ensimismada; ¿qué puedes ver de malo?, no sé, nada... 
T.: Estabas... me voy a inventar una palabra, estabas "enelmismada"... H.: Si..., "enelmismada", estaba claro, enamorada. Él me quería para él y lo consiguió y cuando me tuvo, es como cuando quieres conseguir algo y luego ya lo dejas allí, ya está, ya lo has conseguido...

T.: ¿Y tu marido quería tener la hija, o era más bien su madre?

H.: No, él no, porque luego en muchas ocasiones me dijo que le habia estropeado la vida. Él es un poco mayor que yo. Pero bueno, había vivido más que yo y habia estado en el mundo más que yo y sabía manejar la situación, sabía dónde se movía y yo no, yo era muy inocente.

T.: ¿De quién te aisló o de qué te aisló?

H.: Pues de todo y de todos. Por parte de su padre, la mayoría de la familia vive en Colombia y nos fuimos a Colombia con la niña. Allí estuvimos 10 años, lo paséfatal, lo pasé muy mal... porque... luego al cabo de los años y todo esto, me di cuenta que se fue allí porque él estaba realmente enamorado de una prima suya, que vivía allí y esa historia continuó en paralelo.

Esta dinámica relacional llevó con el tiempo, después de 17 años de matrimonio y de la aparición de una tercera persona, a la separación de la pareja. Sin embargo la separación no modificó las cosas sino que acentuó el maltrato tanto físico a través del hijo como sobre todo psicológico:

T.: ¿Pero cuándo te separaste de tu marido?

H.: Pues en el 94. Aunque bueno, separarnos, separarnos..., pues no, psicológicamente yo segui muy unida a él hasta hace poco... porque me seguía manipulando, es un manipulador nato.

T.: ¿Cómo era el maltrato psicológico? ¿Se basaba en qué?

H.: Me daba maltrato psicológico silencioso, de ese que nadie se podia enterar. Sabia hacerlo muy bien, sin que se notara Y últimamente a través de mi hijo, una manipulación a través de Ramón, porque sabe que estoy muy unida a él. De que lo maltrataba a él, no me di cuenta hasta hace 3 años, que ya no ve a Ramón. Le pegaba, lo manipulaba en contra mía, pero una barbaridad. Y qué se le puede hacer a un hijo que tiene la mentalidad de 7 o 8 años..., aunque haya cumplido los veinte...

T.: ¿Pero te amenazaba de qué forma?

H.: Bueno pues que a míme iba hacer no sé qué, me iba hacer no sé cuánto, que yo era una puta... Y bueno pues, manipulaciones, improperios y....

\section{Dependencia Afectiva en la Primera Relación de Pareja}

La aparición del maltrato en la relación de pareja, Heidi la explica en función de la fuerte dependencia que desarrolló hacia Antonio, el primer marido, a causa de su falta de referentes internos.

T.: ¿Y cómo es que has mantenido este tipo de relación durante tanto tiempo?

H.: Era la dependencia, tenía una dependencia muy fuerte de él, a nivel afectivo, no económico. Por qué yo siempre he trabajado, siempre me he 
defendido muy bien a nivel económico. Nunca tuve que pedirle dinero a él para comprarme algo, porque yo ganaba mi dinero. No tenía esa necesidad. T.: ¿Y de qué tenías necesidad de él?

H.: Pues es algo inexplicable: cuando dependes de alguien emocionalmente... Crecí con él, me hice con él, era como, como su perrito...

T.: Ya, la voz de su amo... Vivías a través de él... ¿Tú sabías lo que querías y lo que no querías?

H.: No, no lo sabía. Yo era muy inestable. Bueno... yo iba en función de él, quizás también era cómodo. A parte, él era el que decidía para todo. En ese sentido nunca lo había pensado, a lo mejor también por comodidad. Claro es que ahora empiezo a ver las cosas desde otro punto de vista.

T.: Puede ser una comodidad que viene del hecho de que, al no desarrollar un criterio propio, se toma uno de prestado. Es como el prêt à porter, o el vestido a medida... Si voy y encuentro un vestido hecho pues me lo pongo y ya está...

Y en cuanto a la educación: ¿tú te encargaste de la educación de tus hijos siempre; no te ayudó él nada en la educación?

H.: Mis hijos los he educado yo. Él no, para nada, al contrario. Siempre lo he dicho: he sido niña, madre y luego mujer. Aprendí a ser mujer hace muy poco. No sabía serlo.

T.: Niña, madre ... y entonces ¿con él qué eras?

H.: Nada.

T.: Cuando dices mujer, quieres decir persona o quieres decir...

H.: Persona también, claro..., adulta, y poder decidir por mi misma, saber lo que quiero, saber amar....

A través de esta relación Heidi esperaba compensar sus déficits de autoestima, pero lo que consiguió fue aumentar la dependencia y someterse al maltrato. Hasta que con un largo trabajo terapéutico no logró desvincularse de esa regulación socionómica compensatoria, todo su deambular por los servicios médicos o psiquiátricos fue un confirmar una visión de sí misma como enferma, cada vez más enferma.

\section{El Proceso Terapéutico}

La dificultad para poder hablar de su experiencia del pasado preside el proceso de terapia de Heidi en el grupo durante muchos meses. A pesar de tener la oportunidad de hacerlo en alguna sesión individual, Heidi se reserva a la espera de alguna ocasión que ella considere adecuada para revelar el secreto del que no puede hablar por falta de confianza, sentimiento de culpa y vergüenza. En una sesión posterior, casi un año después el tema de conversación es precisamente la necesidad de hablar y la dificultad para hacerlo.

H.: A mi hay cosas que me han pasado que me hubiera gustado hablar con alguien con quien tuviera confianza, que yo supiera que esta persona me está escuchando y pudiera darme su opinión... Yo no estoy diciendo que 
tenga todavía ese problema. Lo he tenido, y he estado, desde pequeña, con problemas. Y... no se ha solucionado, es decir, yo siempre decía, me hice yo a mi misma, porque nadie me daba una solución, nadie me ha dado las herramientas... Hay cosas que necesitas ayuda, o sea... Y llega un momento en que dices... a ver, ¿con quién puedo hablar yo esto?... Yo ya he tenido como cinco o seis psicólogos. Y no he solucionado nada, porque no me transmitían confianza. Nunca habia compartido estas cosas con nadie, porque te vuelves reservada... Te cuesta transmitir lo que tienes, tienes miedo porque son cosas que no suceden normalmente, y cuando sucedieron, te han hecho sentir mal y te han hecho sentir culpable... y entonces tienes miedo a transmitirlo y a la opinión que tengan de ti, a la idea que se formen de ti y al juicio... Y cuando llevas una culpa encima y todo este peso encima, es muy difícil transmitirlo a nadie, porque, a parte, las personas que te han hecho daño siguen vivas y les sigues teniendo miedo... Cuando son personas tan cercanas ... que están ahi todavía... Llega un punto en que necesitaría que me vieran de otra manera. Que vieran que yo he evolucionado..., que me vieran como una persona, como lo que soy ahora. No que me sigan viendo como ellos me veían antes. O lo que habian hecho de mí... Pero, por ejemplo... la persona que más daño me ha hecho en mi vida, no ha cambiado nada. Físicamente no puede, pero mentalmente si, y lo malo es que cuando estoy delante de él, se me desmorona todo, y entonces digo, a ver, Heidi, ¿qué has estado haciendo hasta ahora? Entonces digo relájate, piensa en todo lo que has hecho, piensa quién eres, que tú vales mucho, o sea, claro que sí que hablo conmigo misma y no pasa nada, es él, pero me afecta, porque claro, tiene un trato con tus hijos, tiene un trato con tu marido y es diferente con todos ellos, ¿me entiendes? Y entonces...

La prosecución del diálogo, centrado ya sobre el maltrato de los padres, elude sistemáticamente el tema del abuso sexual, aunque le es aplicable totalmente, orientando la atención de la audiencia sobre el autoritarismo del padre y la rebeldía de la hija.

T.: ¿Y a qué te refieres ahora?

H.: A poder hablar de lo que pasó, de las cosas que pasaron... por qué pasaron, por qué lo hicieron..., por qué motivos.

T.: En ese caso, ¿con quién tendrías que hablar?

H.: Con mis padres; mi padre sobre todo. Mi padre fue el más culpable de todos.

T.: Tu padre. Parece que es un tema que te remueve especialmente, hablar de él.

H.: Todavía me cuesta. Es que, claro... luego con la perspectiva del tiempo, dices ¿pero por qué? Es doloroso... doloroso. Pues ahí, dentro de ese hogar, se han violado todos mis derechos, como persona y como niña. 
T.: ¿Tenías consciencia de alguno de tus derechos?

H.: A ver... no consciencia en sí, porque, al fin y al cabo, era una niña, pero me imagino que cuando alguno de esos derechos se violaba, sabía diferenciar lo que estaba bien y lo que estaba mal, porque habia vivido lo bueno y había pasado lo malo y... entonces claro, sabía diferenciar una cosa de la otra.

T.: Pero luego, cuando el maltrato lo recibiste tú, ¿cómo lo vivías?

H.: Estás en un círculo tan cerrado, que te sometes; $y$ vas adquiriendo una dependencia. Y esa dependencia hace que obedezcas, porque no hay nada más.

T.: Ahi también es dónde te cuestionas si te acomodaste...

H.: Sí. Y como vida en familia es lo que conocí. No conocía otra, porque esa, según ellos, era la que valía; eran los padres.

\section{El Reconocimiento del Abuso}

Esa oportunidad llegará en una sesión posterior. En el grupo se está hablando del perdón y a este propósito comenta el terapeuta:

T.: La gente antes, en el lecho de muerte, pedían confesión, se sinceraban, era el momento de hacerlo.

H.: Para mí sería que mi padre en su lecho de muerte me pidiera perdón

T.: ¿Y qué tendría que decir para pedir perdón, realmente?

H.: Que se ha equivocado en mucha cosas, en querer someterme, en reproches, en que nada lo hago bien.

T.: ¿Tu padre se podría arrepentir de algo?

H.: De los abusos. Es que nunca he hablado con él de esto. Para él no han ocurrido... Tenía que someterme de alguna manera. Y fue la única que encontraron.

T.: De someterte.

H.: Si, que me iban a domar. Y es lo que nunca consiguieron, nunca hubiera estado a su lado.

T...: ¿Cuando hablas de abusos...?

H.: Abusos sexuales. Para mí me han herido más psicológicamente que las marcas que me dejaba en las piernas.

T.: ¿Y tu madre no sabía nada?

H.: Sí que lo sabía. ¿Cómo no lo iba a saber una madre? Ella los sábados iba al mercado, se llevaba a mi hermano y me dejaba sola con él

T.: Dejaba el camino libre. Era cómplice.

H.: Totalmente, totalmente

T.: ¿Y eso, cómo se perdona?

H.: Se perdona porque tienes que seguir, tienes que llegar a sentirte limpia y sentirte libre. 


\section{Macroestructura del Discurso de Heidi}

A partir de ese relato autobiográfico es posible aventurarse a diseñar una representación gráfica (figura 6) de la organización macroestructural del discurso de Heidi en función de su posición en el mundo y del grado de desarrollo e integración los sistemas de regulación moral.

Figura 6

Macroestructura del discurso de Heidi

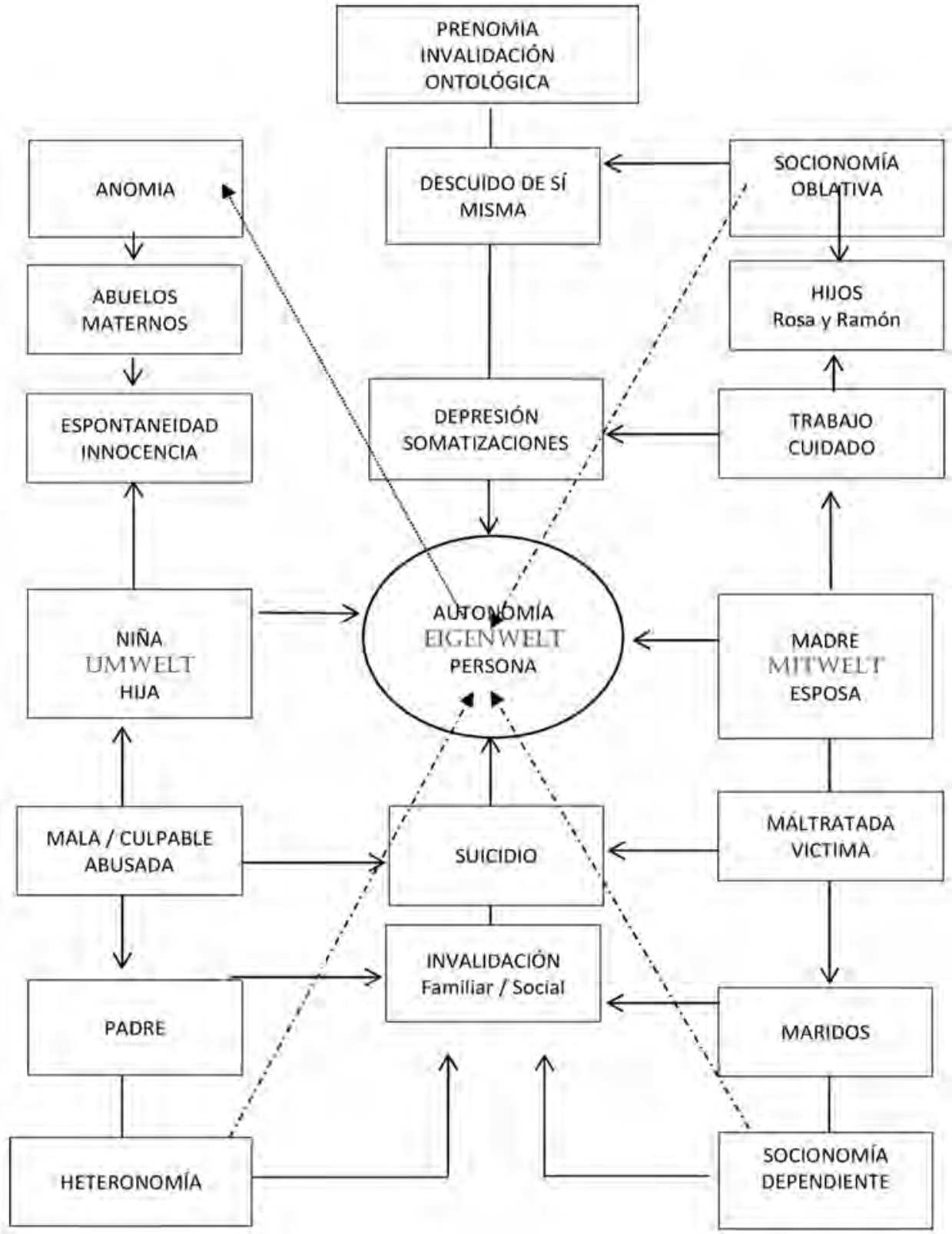


La macroestructura del discurso de Heidi muestra la dificultad para llegar a ser una persona autónoma, a la vez que la imposibilidad de desarrollar un mundo propio (Eigenwelt) en el contexto relacional en que se ha desarrollado su vida. En sus propias palabras, primero fue niña, después madre y después mujer. Existe un déficit evolutivo, que arranca ya de la primera infancia, que afecta a la validación ontológica: "no debería haber nacido". Hija de un pecado de origen, en la familia paterna estaban empeñados en que fuera abortada; pero aunque estigmatizada, nació hija de la vida.

T.: ¿Entonces, según dices, no te tocaba haber nacido?

H.: Si pudiéramos haberlo visto desde ese punto de vista, hubiéramos sido más felices todos.

T.: Túhubieras sido afeliz, porque no habrías nacido. Tampoco infeliz, afeliz H.: Esa célula no se forma y ya no estoy aquí (ríe un poco). Piensa que la abuela y la bisabuela (paternas) iban al río a hacer cosas para que yo no naciera A mi madre le tiraban piedras a la puerta cada día, la apedreaban, la insultaban, le hacían la zancadilla para que tropezara, para que abortara. T.: Vaya que fue un embarazo, no sé si deseado o no, pero sí conflictivo. H.: Sí. No sé si mi madre..., no se lo he preguntado, si en algún momento del embarazo desé no tenerme, eh... no lo sé, no lo sé...

T.: Pues tienes que darle gracias a la vida

H.: Sí, siempre, siempre, y me considero una luchadora

T.: La vida quiso que nacieras y ahí estás.

H.: Y darle gracias a eso, me considero una luchadora pero, total, sí, porque he tenido que luchar siempre por vivir. Y bueno... también creo que, luego ya cuando vas creciendo y eres adulto las cosas las van marcando... los caminos que hay tantos, los vas escogiendo tú mismo, no los escogen los demás (...)

Sus padres, pronto la dejaron al cuidado de los abuelos, que la trataron con amor y la educaron en la espontaneidad, entre los cuatro y ocho años, pero no pudieron suplir la ausencia de los padres en la primera infancia, sobre todo porque su acción tutorial se vio interrumpida cuando éstos se la llevaron a Suiza a los ocho años.

"Habia veces en que los niños decian para herirme: "Ah, porque tú no tienes padres... tus padres no te quieren ... están fuera”... Habia un momento que deseaba que llegara un coche por alli, que vinieran mis padres a buscarnos... Siempre he deseado un padre de verdad; sí, un padre y una madre, para poder presumir delante de los niños del pueblo; así ya no podrían decir que no tengo padres, que solo tengo abuelos".

Este descuido marcó un déficit prenómico de nutrición afectiva, falta de estima ontológica, que probablemente ha arrastrado en toda su vida sentimental, "por eso en cuanto veía una miajita así de cariño ; huuu..!, me enganchaba como una lapa, y siempre acababa escaldada. Pero no lo sabía ver. Yo no tenía la intuición esa de... Soy muy inocente, soy como una niña y me da 
rabia también ser una niña".

El reencuentro con los padres se enmarcó en una relación autoritaria y de abuso sexual, hasta el punto de llegar a sentirse mala y culpable por ello, de modo que la regulación heteronómica ha tenido en ella una función de sometimiento.

"El recuerdo está ahí toda la vida, esto no lo puedo olvidar. Me gustaría que mi padre me pidiese perdón, sí. Sería una manera de reconocer que me ha hecho daño... Me estaba haciendo daño porque era la manera de someterme, porque contestaba, porque no callaba, porque no consentía, porque no estaba de acuerdo, porque era contestaria... Era un castigo. Era la forma de someterme... Yo no sabía por qué era mala. Me decían que porque no obedecía, porque no era buena hija, porque no les quería. Me estaban obligando a quererles, cuando yo no los veía como padres".

Invalidada en sus orígenes y sometida a la sujeción paterna, a los 18 años entra en el mundo de las relaciones sociales (Mitwelt) a través de la relación amorosa con Antonio, que deriva en una relación de dependencia invalidante.

"Yo pensaba que, teniendo un bebé y teniendo un marido, iba a ser todo diferente y no fue. Porque me daba maltrato psicológico silencioso, de ese que nadie se podía enterar y yo siempre era la mala para todos, y la rebelde, y fue terrible.... El trato de él conmigo no era de igual a igual, a mi me ha visto siempre inferior y como tal me trataba. O sea él sabia mis debilidades, mis puntos flojos y mis problemas emocionales, y entonces, jugaba con todo eso.

T.: ¿Cómo te veías tú sin él en aquella época?

H.: Que no sería capaz de funcionar en el mundo sin él... Es más, cuando nos dejó estuve sin funcionar mucho tiempo. No podia; me quedé que no sabia por dónde tirar. No sabía qué hacer, no sabía adónde ir, ni de vacaciones... No sabía nada... No entendía nada.

T.: No entendías nada. Simplemente te sentías perdida.

H.: No, no; me sentía mala. Muy mala. Yo era muy mala. Porque yo era mala. Para mi familia, para todos. Porque me dejó esa persona, tan buena tan trabajador, tan luchador...

T.: ¿Qué hacías para ser mala?

H.: Pues según ellos que yo lo trataba mal; que no le hacía caso, no era una buena mujer, no era lo suficientemente sumisa, no era lo suficientemente trabajadora en casa. No era suficientemente mujer.

T.: Ahí hay algo más que hacer las cosas mal. En ese juicio hay una invalidación. Una negación de valor. No solamente no hacer las cosas bien, sino, no valer.

H.: Exacto; no valía. No valía para nada.

A esta invalidación constante del marido hay que añadir la del padre e incluso la de la madre que confluyen no solo en la infancia, sino también durante toda la edad adulta 
T.: Eso te lo hacía sentir tu marido o...

H.: Eso fueron las palabras de mi padre. Cuando nos separamos. Porque claro, de cara a la familia tuvo que irse, porque era insostenible la vida en casa.

T.: ¿Y tu padre te dijo que no valías nada cuando tu ex te dejó?

H.: Bueno, paraél nunca he valido nada, y pues en aquel momento, menos...

T.: ¿Y tu madre?

H.: Igual, igual... Incluso, mi madre me dijo respecto a Ramón: “¿Cómo es que has tenido otro hijo?", "mira lo que has traído de Colombia".

T.: O sea, te echaban en cara que Ramón naciera con alguna deficiencia.

H.: Incluso llegaron ajustificar que Antonio sefuera de casa, porque ¿cómo se puede aguantar un niño así en casa? ¿Cómo puede estar una persona así que trabaja tanto? Yo tenía a Ramón y tenía a Rosa y trabajaba. Yo he trabajado siempre y he estado siempre por mis hijos.

Esta invalidación ha continuado con el segundo marido a través de la enfermedad. Inicialmente Heidi y Marcos mantuvieron una relación sin convivencia, cada uno en su casa, que es como le gustaba a ella. Pero cuando fue progresando su enfermedad, el dejó su domicilio y se fue a vivir con ella, convirtiéndose gradualmente en su enfermero, contribuyendo así a confundir el amor con la dependencia

Heidi intenta abrirse camino por sí sola, y únicamente cede cuando se hace cargo de ella un hombre. Se regula prenómicamente, asumiendo la tarea de cubrir sus necesidades y las de los suyos, "hasta que el cuerpo aguante”. Por eso somatiza hasta el extremo, sobre todo muscularmente, los conflictos existenciales. La suya es una crisis del narcisismo meritocrático: "Tanto hago, tanto valgo".

Pero todo en su vida se conjura para impedir su emancipación como persona adulta: el sometimiento y abuso de los padres; el internamiento en un colegio de monjas durante su adolescencia, la relación de dependencia, maltrato y sujeción con el primer marido, la necesidad de dedicar su vida al cuidado de su hijo y al sustento de la familia, las enfermedades somáticas y psíquicas. Solo quedan preservadas de esta invalidación el paréntesis de su infancia con los abuelos, los éxitos deportivos en el internado, la realización profesional como cocinera y la autonomía económica laboral, fruto de su esfuerzo personal.

\section{Intentos de Suicidio}

En este contexto de invalidación nuclear constante, de culpabilización, de dependencia y sometimiento aparecen las ideas y los intentos de suicidio ya desde la infancia y adolescencia.

T.: Y el hecho de que te castigaran ¿cómo lo vivias?

H.: Muy mal, muy sola, muy injusto. Me sentía sola en esos momentos me sentía abandonada por mis papas y por mis abuelos, porque dejaron que me fuera con ellos. Hubo un momento en que me bajé a la piscina y no quería salir, me quería dejar hundir, con la boca abierta. Y el socorrista 
me sacó; me tuvo que hacer el boca a boca.

A esta invalidación ontológica le ha seguido la física, debido a la fibromialgia y demás síntomas somáticos:

Estaba en un momento desesperado de mi vida, y al verme ya sin poder trabajar que ha sido el desahogo que he tenido siempre a todos estos problemas... que ha sido el darle amor a mis hijos y el trabajar... Al no poder, al verme incapacitada para trabajar, dejar mis cosas, dejar mi trabajo, mi negocio, estaba en un momento limite ya. Por mucho que Marcos estuviese a mi lado, que mi hija estuviese a mi lado, que me quisieran, en esos momentos no es suficiente, eso no lo tienes como en cuenta, no: eres egoísta en ese sentido.

... y la psicológica después, el hundirse anímicamente, la depresión

H.: Bueno el problema al principio pues cuando me enfermé, con la depresión, pues... el doctor me dijo lo que más conveniente era que fuera al psiquiatra o psicólogo, porque con la medicación solamente no iba a... porque los ataques de ansiedad ya eran tan crónicos de ir al hospital, a urgencias cada dos por tres, de llamar, de sentir ya ese vacío, el no poder dormir y cuando me quedaba dormida era como si me cayera al vacio, era un querer sin vivir ya... A mí me ataba mi hijo Ramón, me ataba Ramón nada más... aunque intenté muchas veces dejar de vivir... Y eso aún me pasa por la cabeza a veces, y luego me siento fatal, cuando viene ese sentimiento, me siento muy mal

T.: ¿Y lo has tenido siempre, o...?

H.: Desde la adolescencia. Pero, era muy continuo, y siguió hasta el punto de asustarme yo misma, además trabajando en cocina con cuchillos, porque..., son como impulsos, y en ese momento se te lleva..., lo haces y ya está. No es como pensado..., algo meditado y pensado, como ha ocurrido alguna vez...

En estas últimas palabras Heidi alude a algunos episodios en que hasta había pensado en incluir a su hijo en el intento de suicidio, como cuando fue caminando con él hasta el puerto y no llegó a tirarse al agua porque la detuvo un paseante que la vio muy mal.

En una ocasión fui con Ramón para... acabar con la vida de los dos. Y... y no lo llevé a cabo, pero lo medité y lo pensé... Caminé hasta el puerto con él... fue una caminata larga... sí, una caminata larga hasta allí... sabía a lo que iba. Y todo el camino con la mente vacía, no pensaba nada, muy extraño...".

En otra ocasión posterior, esta vez sola, subió al terrado de su casa, con la intención de tirarse a la calle...

H.: llegó un punto que tenía muchas lagunas de la depresión, no sé si será por la cantidad de medicación que tenía..., pero era un bienestar, me sentía bien... O sea, ahora recordando en el tiempo y analizándolo... no 
era felicidad, era bienestar...

T.: o sea, era la dulzura de la muerte

H.: la dulzura de la muerte... qué frase... sí... exacto... sí... la dulzura de la muerte porque yo me estaba dejando morir. Es más, voy a decir algo que no habia dicho hasta ahora (silencio)... Un día... en mi edificio no hay ascensor y empecé a subir para llegar a la terraza, descalza, era invierno y llegué al piso de arriba... Me quería tirar de la terraza porque digo "si me tiro de mi piso me voy a romper una pierna, no me voy a hacer nada más". Pero no fui capaz de abrir la terraza porque no tenía fuerzas y empecé a bajar sentada los escalones; pero me di cuenta que no tenía las llaves de casa... porque si me voy a tirar dejo las llaves... O sea, lo dejé todo, o sea... iba en pijama, descalza; un pijama así como un chándal finito y estuve esperando hasta que llegó él... Y me dijo: "pero qué mal estás, mira que estás mal ¿eh? Pasa, pasa, pasa”... Como a una niña y recuerdo aquello. Me reñía como una niña, igual. Como si fuera una niña. Y para él era una niña, era una "nina", además me decía "nineta".

T.: O sea, tú te posicionaste como en un rol de niña con él, es decir, dame todo el cariño que no me dieron mis papás

H.: Sí, exactamente: es que al final yo le llamaba lo mismo, le decía papa y él me decía "nina"

T.: Osea, como un bebéque no tiene que [H: si] hacer nada por símismo y...

H.: Era como un refugio, fue como encontrar un refugio

T.: Lo que pasa es que ese padre nutritivo era más bien devorador

El último intento se produjo de nuevo, como el primero, en una piscina. La sacaron dos compañeras y la ingresaron en un hospital.

H.: El punto de inflexión fue el año pasado, como por el mes de marzo que fue el último día que yo fui a la piscina. Ese día, precisamente, tenía que venir a sesión. Pero, claro, falté; hasta ahora no habia explicado por qué. Me rescataron entre dos compañeras y me llevaron en una ambulancia al hospital. Yo sentía que me daba un ataque de ansiedad muy fuerte, sentia que me ahogaba en la piscina... y me dejaba... quería ahogarme... Yo tenía la voluntad de decir "me dejo ahogar"

T.: $Y$ al tocar fondo de la piscina... de alguna manera, ¿tocaste fondo en ti misma?

H.: Sí (emocionada) tenía que tocar fondo en mí misma

T.: Mmh..., mmh. A esa dulzura de la muerte le viste la amargura

H.: Cuando estaba en la piscina me vi yo... y vi a Ramón; no vi a nadie más, no vi a Rosa... me vi yo y a Ramón, a nadie más. Me estaba viendo e intentaba agarrarme a mí... eso no lo entiendo... supongo que estaba intentando agarrarme a la vida...

T.: Y la vida solamente era la tuya... O sea, por tanto, tenías que agarrarte a ti misma... Si quiero vivir tengo que ser yo quien emerja del agua. Ahora 
es como si por primera vez fueses tu madre y tu padre, o sea, ahora eres tú la que asume el rol de cuidarte.

Ese fue el momento de tocar fondo, ya iniciado el proceso de terapia de grupo, a partir del cual, Heidi fue renaciendo como el Ave Fénix.

\section{La Curación por la Palabra}

La psicoterapia ha sido definida como "la curación por la palabra". Con frecuencia se escribe, incluso por parte de los mismos pacientes, como un espacio donde poder hablar, desahogándose, identificándola con la función catártica que sin duda tiene, pero en la que evidentemente no se agota. Más bien es el espacio donde la experiencia puede resignificarse y reconstruirse a través del cambio de narrativa, del victimismo a la autonomía.

T.: Tú decías que justamente necesitabas a alguien con quien hablar...

H.: Tuve bastantes psicólogos. A lo largo de mi vida no era la primera vez que iba al psicólogo. Siempre he considerado que el psicólogo es la persona que más te puede ayudar y que más te puede comprender. Pero, no había encontrado a la persona... Pero romper esa barrera sí, fue muy importante para mí. El empezar a entenderme desde el principio para que yo fuera viendo las cosas... vas hablando y vas viendo... Sobre todo el escribir, siempre he escrito, pero lo rompía, yo nunca he dejado que leyeran mis escritos, sentía vergüenza de que los leyeran. Entonces cuando tenía un cuaderno, pues lo rompía, o lo quemaba... Es que yo tampoco no sabía que existía esta terapia...

T.: Esta terapia de reconstrucción.

H.: No lo sabía que existía, hasta que llegué aqui. Y para mí fue mi salvación. Que gente que me conocía me dice: pero ¿qué te ha pasado?, porque estás muy cambiada, muy bien eh. Digo perfectamente. O sea de víctima, esta parte de victimismo, ya no existe, ya no existe

T.: Ajá, eres responsable de tu existencia

H.: Exactamente, es lo primero que tienen que sacarte para poder caminar. Dejar de ser víctima, y el verte a ti misma como persona, y claro, el ir de "ay, pobrecita", el ir de víctima, al sacarte esa etiqueta, te sacas un peso tremendo de encima. Porque somos víctimas, porque queremos serlo, porque nos va bien ir de víctimas...Tengo que mirar al futuro, tengo que vivir, vivir siempre es para adelante no para atrás.

\section{La Superación de la Dependencia: El Trabajo con la Pareja Actual}

Hasta la aparición de los síntomas, Heidi se definía como una mujer resuelta, activa, ejecutiva y divertida. Con la fibromialgia progresivamente va restringiendo las actividades hasta la situación actual. La demanda explícita se refiere a síntomas físicos relacionados con la fibromialgia, si bien describe aspectos como la confusión, la falta de diálogo real con su pareja reciente, con problemas físicos que también implica inapetencia sexual y alimentaria, e incluso agorafobia, dificultades funcio- 
nales (no puede cocinar) y episodios distímicos y depresivos que sugerían aspectos mucho más profundos de dolor y heridas en la esfera emocional y afectiva. Refiere también pérdidas de control, sensaciones disociativas, sensación de culpabilidad y de cobardía, e incluso describía el intenso amor por su pareja actual como "doloroso” físicamente, "ya que nunca había sentido nada igual”. Casualmente, una vez consolidó su amor con Marcos, los síntomas avanzaron a pasos agigantados, añadiéndose nuevos diagnósticos que la incapacitaron severamente, pasando a depender totalmente de él, hasta la ruptura reciente de dicha relación.

En la primera sesión plantea una buena imagen, positiva, muy ligada a Marcos, su pareja, a quien conoció hace unos siete años. Más adelantada la terapia, revela problemas personales y de pareja, empeoramiento de los síntomas psicofísicos con reagudización de las crisis de ansiedad. Avanzado el proceso terapéutico, a medida que aumenta la capacidad de autoafirmación de Heidi, se produce un distanciamiento progresivo de Marcos, sobre todo tras descubrir en él adicciones a drogas y al sexo, hasta tomar la decisión unilateral de poner fin a la relación, por la anulación e invalidación progresivas que había ido sufriendo.

T.: Hay una cosa interesante a nivel más general, que luego se ha reproducido con tus parejas. ¿Sabes a qué me refiero?

H.: Si, al maltrato... Pero lo interesante para mi es que creo que con Marcos lo he roto, lo he podido ver; y además fue ya este último año, lo vi claro. Pero tengo un escrito de hace ya cuatro años donde Marcos no queda bien parado a nivel de relación. Habia una carencia emocional y luego como una dependencia al maltrato que se iba repitiendo el patrón que tenía siempre de sometimiento.

T.: Incluso el maltrato es una demostración de que se fijan en mí, que me tiene en cuenta: te castigo a través de someterte y a eso le llamo "amor". H.: He sido niña y he sido madre, pero no mujer. Ahora soy mujer. Por eso cuando yo empecé a ser yo, discutimos con Marcos hasta que se fue... Lo que me hace sentir bien en ese proceso es que lo hice yo sola, no lo comenté con nadie y es como lo quise hacer, de esta manera.

T.: Un proceso personal y propio

H.: Sí. Eso me hace sentir muy bien.

T.: ¿Y la fuerza, de dónde la sacabas? Porqué has estado depre, durante mucho tiempo...

H.: Cuando estaba depre no tenía fuerza

T.: Pero fue dejar a Marcos y aqui todo el mundo vimos un cambio tremendo.

H.: Yo sali de la depre antes de dejarlo, Si no, no lo hubiera dejado nunca.

T.: Ya, pero ¿qué te hizo dar ese giro?

H.: Pues el pensar... "tú siempre te has valido por ti misma, siempre has sacado todo adelante y con lo que tú sabes ahora, con lo que has aprendido, ¿te estás permitiendo todo esto? " Es que empecé a sentir un bienestar dentro de mí... el querer hacer las cosas por mí misma... saber que me 
estaban manipulando... "Pero bueno... ¿a ti cuándo te ha manipulado alguien? Pues, tu marido, el padre de tus hijos... pero eso fue hace mucho tiempo... ¿y ahora se va a repetir? Pues no, no lo permitas".

Recuperado el control de la medicación, que había dejado en manos de Marcos, asume la gestión de los aspectos médicos de forma más autónoma, llegando a descubrir un cierta sobredosificación medicamentosa que la hacía estar "más confusa, dormitando enlentecida”, durante toda esta última etapa.

Después de la ruptura con Marcos el cambio es espectacular, tanto a nivel físico como mental. Heidi abandona las muletas en la que se apoyaba para asistir al grupo de terapia, se desprende de la mascarilla de carbono que la protegía de la aspiración de las sustancias químicas en suspensión y que hacía difícilmente inteligible su discurso, está más comunicativa y participativa, recupera movilidad y agilidad. Las puntuaciones en los tests de depresión han pasado de muy grave a muy leve en el espacio de 5 años.

\section{Resiliencia}

El proceso terapéutico de Heidi es una muestra fehaciente del poder de las personas para recuperarse de los traumas sufridos y (re)construir los eslabones perdidos o rotos de la cadena evolutiva en el camino hacia la autonomía. En este proceso tiene un gran valor y trascendencia la recuperación de las partes sanas de la experiencia pasada, en su caso la vinculación segura con los abuelos y las experiencias del propio valor: los deportes, el trabajo como dependienta en Colombia o en los restaurantes que ella misma montó

T.: Dices que hay cosas en la mochila que todavía tienes que echar

H.: Hay cosas que, que duelen, cosas que son inevitables, pero esos momentos los supero mejor que antes.

T.: ¿Y cómo lo haces?

H.: Pues... mmm ... me voy a un sitio seguro

T.: Un sitio seguro

H.: Sí, me voy a un sitio seguro y desde ahí pues pienso que eso ya está atrás, que estoy bien, que estoy siendo querida, que nada me puede hacer ya daño, si yo no quiero; sin desconfianza...

T.: ¿Este sitio seguro es tu infancia con tus abuelos, libre en la naturaleza...?

H.: Sí, esa parte es mi tesoro... es donde me siento segura, a donde tengo que ir cuando, por ejemplo, me dan ataques de ansiedad, mi sitio seguro siempre es ahí... Y luego pues me lo pasé muy bien también en el internado, todo hay que decirlo, tenía amigas... eh, con el deporte lo pasaba pipa, era la mejor, siempre la mejor y yo bueno, pues el ser lider en algo... Ahi yo era, bueno, sensacional, y ni mis padres, ni mis profesores a eso no le daban importancia... O, por ejemplo, leer libros, que tampoco le daban importancia, si no era un libro de texto. Yo en mi adolescencia me tragué un montón de libros, porque ahi yo me metía en las historias y me evadia, 
ahi es donde yo soñaba... Hubo una época en la que me gustó mucho la poesía, aún guardo un cuaderno en el que yo escribía poesía.

T.: Me ha recordado mucho eso que explicas a la Heidi; en el sentido de un ser natural, inocente, puro, sano, que vive en la inmediatez de las sensaciones, de la naturaleza, de... No le sale el mal, porque es incapaz de pensar en él... Y ahora puedes recuperar, de alguna manera, esa época inocente, esa época libre...

H.: Sí, me ha servido mucho para salir adelante y salir después, porque toquéfondo totalmente. Me ha ayudado mucho. Yme está ayudando mucho.

La historia de Heidi, es una historia de resiliencia. Reproduce con las variaciones propias del caso, las características comunes a la mayoría de historias de abuso sexual en la infancia. La presencia del abusador en el entorno próximo de la víctima, en ese caso el padre. La distorsión en la propia experiencia relacionada con el abuso, en este caso la violación como un "castigo" por ser "mala hija”. La construcción de las relaciones amorosas como sometimiento y la transferencia de esta concepción a las relaciones de pareja, dando lugar a una asimetría deficitaria (Villegas y Mallor, 2010) que derivó en maltrato psicológico en el primer matrimonio y en dependencia y sobreprotección en la relación con Marcos, la segunda pareja.

Lo que llama la atención en el caso de Heidi es la intensidad de la sintomatología psicosomática, que acompañaba a la depresión, la dependencia y la agorafobia en la última fase de su relación de pareja, y que remitió rápidamente en cuanto se fue liberando de ella. El significado de este proceso puede entenderse desde la perspectiva del desarrollo moral como un pasaje de la regulación socionómica a la autónoma (Villegas, 2014). Una regulación no integrada y deficitaria a partir de la experiencia de abuso, basada en la confusión del amor como disolución del yo en el otro, del amor como cuidado que exige la contraparte de la debilidad y la enfermedad, del amor como dejación de la propia voluntad.

El proceso terapéutico ha permitido a Heidi retomar los apoyos de una base segura que conservaba todavía en sus recuerdos de infancia con los abuelos, durante la fase anómica; reconectar con su historia de resiliencia manifestada en su capacidad de trabajo para sustentarse por sí misma; valorar la superación de las dificultades extremas en la crianza de los hijos; asumir con valentía la travesía en solitario del desierto del dolor; ejercer la fortaleza para hacer frente al maltrato en su primera pareja y desprenderse de los falsos apoyos de la sobreprotección en la segunda; desplegar la generosidad consigo misma y con sus relaciones más significativas para liberarse de las cargas emocionales destructivas del pasado a través del perdón. De este modo Heidi ha convertido el proceso psicoterapéutico en un camino hacia una autonomía plena, no solo psicológica, sino también afectiva y funcional: ya no depende de las relaciones tóxicas de pareja, ni de las muletas en que apoyarse para caminar o de la mascarilla para poder respirar. 


\section{A Modo de Conclusión}

La casuística particular o los estudios de caso único, no pueden nunca establecer un criterio universalmente válido para extraer conclusiones, pero constituyen un camino abierto a la comprensión del significado profundo de las experiencias patológicas que subyacen al fenómeno estudiado. De la lectura de estos tres casos parecería que se podría extraer la conclusión que los intentos de suicidio solo tienen éxito si afectan simultáneamente a los tres mundos (Umwelt, Mitwelt y Eigenwelt). Este es el caso de Ellen West en quien el conflicto entre el mundo propio (Eigenwelt) y el mundo social (Mitwelt), se dirime a costa de su naturaleza (Umwelt) corporal, derivando hacia la anorexia purgativa primero y el suicidio, después. Por el contrario, ni Eco ni Heidi están enfrentadas con su corporalidad. Eco, aun en sus momentos más bajos, cuida su apariencia y su cuerpo. Heidi, a pesar de su fibromialgia y otros achaques corporales que le afectan, se adapta a sus circunstancias y no rechaza su cuerpo; incluso después de su recuperación surge esplendorosa en su corporalidad.

Pero eso no siempre es necesariamente cierto. Es cierto que Ellen West consigue finalmente suicidarse y no por los medios más estrambóticos ideados con anterioridad, sino por la clásica ingesta de sustancias tóxicas. Pero podría haber sucedido que tanto Heidi, como Eco hubieran tenido éxito casualmente en alguno de sus diversos intentos, según de qué lado hubiera estado el azar. Ellen West no le dejó esta oportunidad al azar. Lo planificó bien, pidió el alta del sanatorio para poder actuar libremente y a sus anchas e, incluso, es posible que obtuviera cierto apoyo de su entorno más próximo (Maltsberger, 1996). En cambio, tanto Heidi como Eco actuaron de manera reactiva a múltiples situaciones o impulsos, sin planificación, dando lugar a imprevistos que interfirieron en su ejecución.

Pero el factor común que une a nuestras pacientes (y esto ya apunta a una posibilidad de extraer conclusiones) es el hundimiento de su proyección existencial, el colapso general en momentos determinados de su vida, de su mundo personal o social sin perspectiva de futuro ni de resignificación del pasado. Haber sobrevivido a estos momentos de colapso abre las puertas a un proceso de terapia en que es posible la resignificación del pasado y la proyección del futuro. Eco, en terapia, ha vuelto a recuperar su voz, su discurso ha sido escuchado, comprendido y validado, y se ha abierto a nuevas experiencias relacionales. Heidi ha encontrado, después de desprenderse de sus relaciones de dependencia y sumisión, de salirse de su posición de victimismo, de liberarse de muletas y mascarillas, el camino hacia la autonomía (Villegas, 2015) y el reencuentro consigo misma. Ellen West escogió otro camino, tal vez porque no tuvo acceso a una psicoterapia, libre de una mirada diagnóstica. En cualquier caso, todas merecen ser consideradas no como casos, sino como personas dignas del máximo respeto. 


\section{Referencias}

Akavia, N. (2008). Writing "The case of Ellen West": Clinical knowledge and historical representation [Escribiendo "El caso de Ellen West": Conocimiento clínico y representación histórica]. Science in Context, 21(1), 119-144. https://doi.org/10.1017/S0269889707001585

Akavia, N. y Hirschmüller, A. (2007). Ellen West: Gedichte, prosatexte, tagebücher, krankengeschichte [Ellen West: poemas, textos en prosa, diarios, historia médica]. Asanger.

American Psychiatric Association (2013). Diagnostic and statistical manual of mental disorders (5 ed.) [Manual diagnóstico y estadístico de los tratornos mentales]. https://doi.org/10.1176/appi.books.9780890425596

Balcells, A. (2017). Seguro de muerte, seguro de vida. Revista de Psicoterapia, 28(106), 57-69 https://doi. org/10.33898/rdp.v28i106.156

Bidart, F. (1990). “Ellen West” en the western night: Collected poems, 1965-1990 [ "Ellen West” en la noche del oeste: poemas recopilados, 1965-1990]. Farrar Straus Giroux.

Binswanger, L. (1945). «El caso Ellen West», en: Artículos y conferencias escogidas. Gredos.

Bordo, S. (1992). Eating Disorders: The feminist challenge to the concept of pathology [Trastornos alimentarios: El desafío feminista al concepto de patología]. En D. Leder (Ed.), The body in Medical Thought and Practice. Philosophy and Medicine (vol.43). Springer. https://doi.org/10.1007/978-94-015-7924-7_12

Laing, R. D. (1982). The voice of experience: Experience, science, and psychiatry [La voz de la experiencia: Experiencia, ciencia y psiquiatría]. Penguin Books.

Lang, H. (1987). Réflexions sur la structure de l'anorexie mental d'après le cas exemplaire d'Ellen West [Reflexiones sobre la estructura de la anorexia nerviosa a partir del caso ejemplar de Ellen West]. En P. Fedida (Ed.), Phénoménologie, Psychiatrie, Psychanalyse (pp. 47-54). Echo-Centurion.

Lester, D. (1971). Ellen West's suicide as a case of psychic homicide [El suicidio de Ellen West como caso de homicidio psíquico]. Psychoanalytic Review, 58(2), 251-263.

Maltsberger, J. T., Clark, D. C. y Motto, J. (1996). The case of Ellen West revisited: A permitted suicide [El caso de Ellen West revisado: un suicidio permitido]. Suicide and Life-Threatening Behavior, 26(1), 86-97.

McLeod, S. (1981). Anorexique [Anoréxico/a]. Aubier.

Minuchin, S. (1984). The triumph of Ellen West [El triunfo de Ellen West]. En S. Minuchin (Ed.), The family kaleidoscope. Images of violence and healing (pp. 195-246). Harvard University Press.

Rogers, C. R. (1989). Ellen West - and loneliness. En H. Kirschenbaum y V. L. Henderson (Eds.), C. R. Rogers: The Carl Rogers reader (pp-157-168). Houghton Mifflin (Trabajo original publicado en 1961).

Sartre, J. P. (1943). L'être et le néant [Ser y nada]. Gallimard.

Ugazio, V. (2018). Storie permesse, storie proibite Polarità semantiche familiari e psicopatologie [Historias permitidas, historias prohibidas Polaridades semánticas familiares y psicopatologías]. Bollati Boringhieri.

Villegas, M. (1981). Ludwig Binswanger: en el centenario de su nacimiento. Anuario de Psicología, 24(1), 3-26.

Villegas, M. (1989). Ellen West: análisis de una existencia frustrada. Revista de Psiquiatría y Psicología Humanista, 25, 71-94.

Villegas, M. (1995). Psicopatologías de la libertad (I). La agorafobia o la constricción del espacio. Revista de Psicoterapia, 7(21), 17-40.

Villegas, M. (1997). Psicopatologías de la libertad (II). La anorexia o la restricción de la corporalidad. Revista de Psicoterapia, 8(30/31), 19-92.

Villegas, M. (2000). Psicopatologías de la libertad (III): La obsesión o la constricción de la espontaneidad. Revista de Psicoterapia, 11(42/43), 49-134.

Villegas, M. (2004). Psicopatologías de la libertad (IV): Anorexia purgativa y bulimia o el descontrol de la corporalidad. Revista de Psicoterapia, 15(58/59), 93-143.

Villegas, M. (2014). Origen, construcción y desarrollo de la dimensión moral en el psiquismo humano. Revista de Psicoterapia, 25(98), 25-40.

Villegas, M. (2015). El proceso de convertirse en persona autónoma. Herder.

Villegas M. y Mallor, P. (2010). Consideraciones sobre la terapia de pareja. Un modelo tridimensional. Revista de Psicoterapia, 21(81), 37-106.

Villegas, M y Mallor, P. (2012). El narcisismo y sus modalidades. Revista de Psicoterapia, 23(89), 59-108.

Villegas, M y Mallor, P. (2015). Estima ontológica, estima narcisista. Revista de Psicoterapia, 26(100), 3-44.

Williams, (2014). El quinto principio. Herder. 